
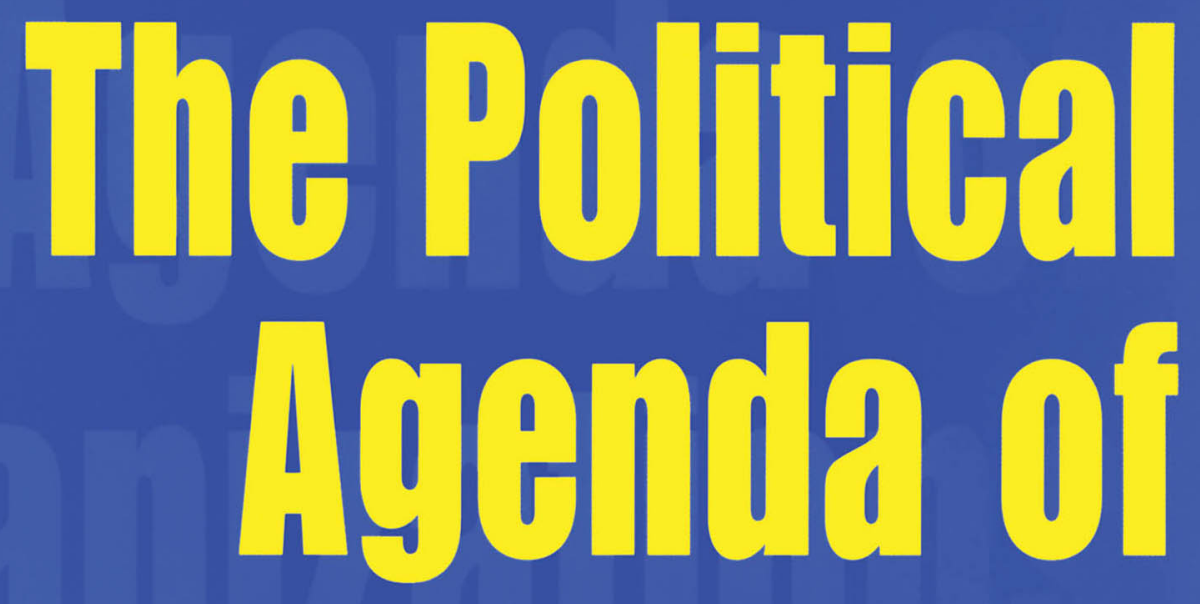

1)

\title{
Yitzhak Samuel
}



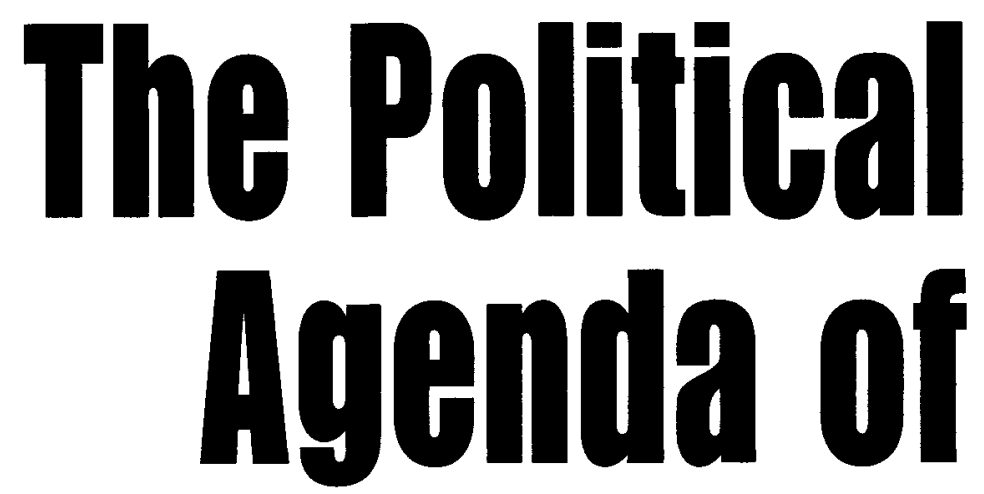

Prganizations 


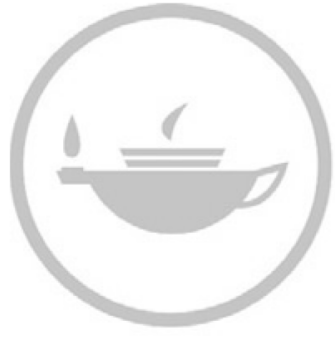

Taylor \& Francis Taylor \& Francis Group http://taylorandfrancis.com 

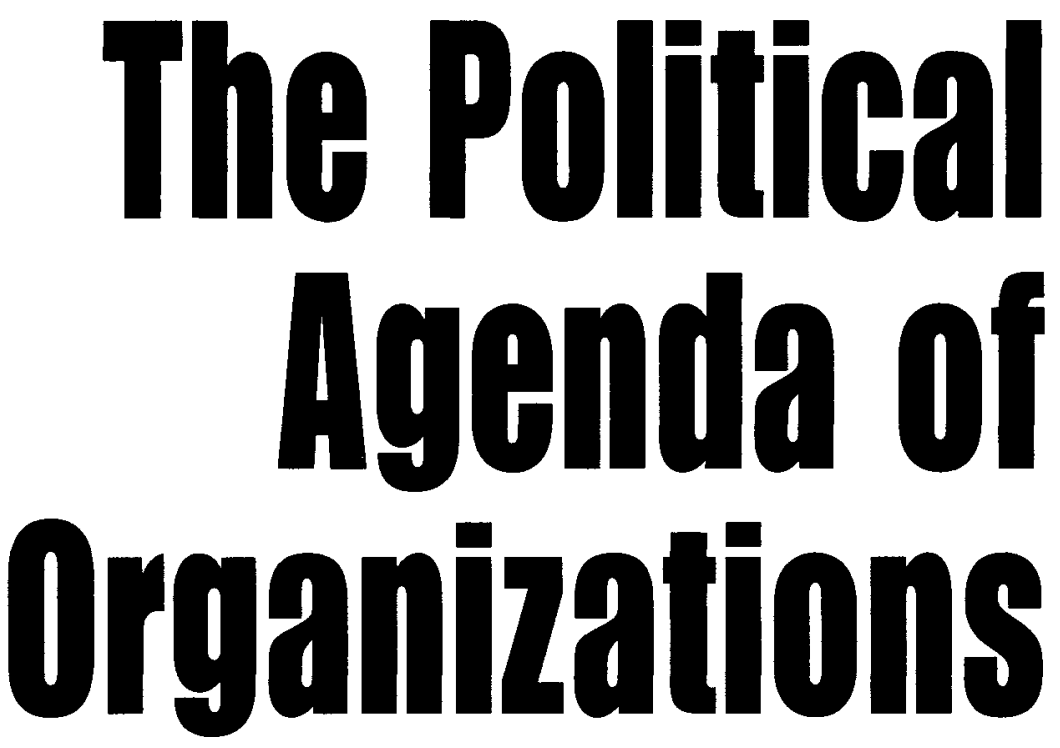

\section{Yitzhak Samuel}


First published 2005 by Transaction Publishers

Published 2017 by Routledge

2 Park Square, Milton Park, Abingdon, Oxon OX14 4RN

711 Third Avenue, New York, NY 10017, USA

Routledge is an imprint of the Taylor \& Francis Group, an informa business

Copyright $@ 2005$ by Taylor \& Francis

All rights reserved. No part of this book may be reprinted or reproduced or utilised in any form or by any electronic, mechanical, or other means, now known or hereafter invented, including photocopying and recording, or in any information storage or retrieval system, without permission in writing from the publishers.

Notice:

Product or corporate names may be trademarks or registered trademarks, and are used only for identification and explanation without intent to infringe.

Library of Congress Catalog Number: 2004051783

Library of Congress Cataloging-in-Publication Data

Samuel, Yitzhak

The political agenda of organizations / Yitzhak Samuel.

p. cm.

Includes bibliographical references and index.

ISBN 0-7658-0260-0 (cloth : alk. paper)

1. Organizational effectiveness-Political aspects. 2. Power (Social sciences) I. Title.

HD58.9.S26 2004

302.3 '5-dc22

2004051783

ISBN 13: 978-0-7658-0260-6 (hbk) 
To the memory of my parents 


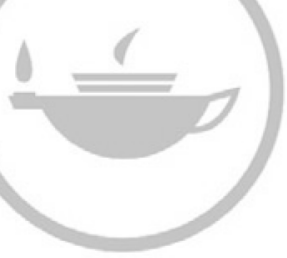

Taylor \& Francis
Taylor \& Francis Group http://taylorandfrancis.com 


\section{Contents}

Acknowledgments ix

Preface $\quad x i$

Introduction $\quad x v$

1. The Essence of Power 1

2. The Theoretical Basis 25

3. The Political Layout 45

4. The Political Agenda 65

5. Perceived Politics 87

6. Political Games 107

$\begin{array}{ll}\text { 7. Interpersonal Politics } & 127\end{array}$

$\begin{array}{ll}\text { 8. Intergroup Politics } & 147\end{array}$

9. Interorganizational Politics 171

10. Managerial Politics 193

$\begin{array}{ll}\text { Conclusion } & 215\end{array}$

$\begin{array}{ll}\text { References } & 221\end{array}$

$\begin{array}{ll}\text { Index } & 229\end{array}$ 


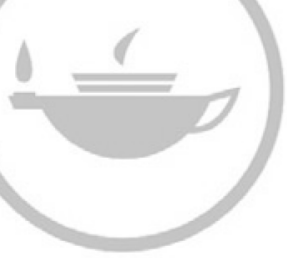

Taylor \& Francis
Taylor \& Francis Group http://taylorandfrancis.com 


\section{Acknowledgments}

It is my pleasure to express my gratitude to the people who encouraged and assisted me to turn the original Hebrew version of this book into an English one. First and foremost, I would like to thank Rebecca Toueg for her professional translation of the Hebrew into English, saving me a great deal of time and effort.

I am grateful to my colleagues at the University of Haifa: Rector Aaron Ben-Zeev; Dean for Research, Moshe Zeidner; Dean of the Faculty of Social Sciences, Arye Rattner; and Chair of the Department of Sociology and Anthropology, Gustavo Mesch for providing me with the necessary financial means to complete this project.

My research assistant Orit Shamir helped me greatly with her library search, checking of references, quotations, and similar tasks. The editor, Anne Schneider carefully polished the text, paid attention to every detail, and nicely arranged the layout of this volume. Paul Corrington prepared the index for this volume. My thanks are also due to Irving Louis Horowitz for his confidence in my work and for the prompt to publish it once the manuscript was completed.

Published book reviews of the Hebrew version, written by my colleagues Ephraim Yuchtman-Yaar, Boas Shamir, and Eran Vigoda contributed useful comments and suggestions, which I have taken into consideration in the present version of the book. Michael Harrison shared with me his publishing experience with American publishers. Warner Burke, Stewart Clegg, and Jim Taylor kindly agreed to review the English manuscript for potential publishers.

The University of Haifa Press and Zmora-Bitan publishers kindly allowed me to publish this volume abroad in English. Special thanks to Miriam Zeidan for her cooperation and assistance in this matter.

Last but not least, I am grateful to my family-Yael, Sigal, Amir, Gil, and Tal for their encouragement and support. My wife Yael closely followed my work, offered her advice and extended her assistance throughout this project, as she has done in all my academic endeavors. 


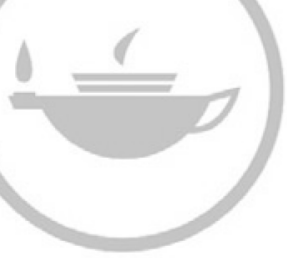

Taylor \& Francis
Taylor \& Francis Group http://taylorandfrancis.com 


\section{Preface}

The history of this book begins about thirty years ago. As a doctoral student at the University of Michigan, I wrote a seminar paper on organizational effectiveness from the point of view of power and exchange relations, and was awarded a prize for the paper and a contract for writing a book on the subject. For different reasons the writing of the book was delayed for a long time and it was never published. In the course of time, some of the ideas presented in that seminar paper were adopted by organization theory, and some of the terms which I employed at that time became current in research and industrial circles.

During the past decade, I returned to address the phenomenon of organizations from the perspective of power and politics. As a lecturer in the Department of Political Sciences and the Department of Sociology and Anthropology, as well as in the College for National Security of the University of Haifa, I taught several classes on this subject. I also gave lectures on the basics of organization politics to executives and managers in various organizations. In my teaching experience, quite often I encountered the same response from my students and trainees, which confirmed that the use of power and politics is deeply rooted in organizational life everywhere. In addition. I noticed that my audience felt uncomfortable discussing this political phenomenon openly and in public, for in their opinion, this subject seemed to cast a shadow over the image of their organization and indirectly on themselves.

Hence, I reached the conclusion that there is a need to address the issue of organization politics, to discuss its causes and to assess its effects. In the light of the knowledge and experience I had gained in organizational politics through my academic and practical work, I decided to put it in writing in a much more detailed and expanded manner than previously, in the form of a reference guide and textbook. This volume is different in content and format from the book that was not published earlier, but it is based on the same thoughts and theoretical ideas that had begun to form since then.

This volume examines all kinds of organizations from a political perspective, analyzing them in terms of social power and politics.' For the purpose of simplification, it employs the concept of political games to describe organizational politics in terms borrowed from the realm of sports, such as contesters, playgrounds, and encounters, as well as rules of the game, strategies and tactics, scores, victories and defeats that refer to various aspects of political games. The main purpose of such political games is the maximization of benefits for the participating players or for their dispatchers. 
The book analyzes the concepts of social power and social influence from several viewpoints. It presents and compares several theories of power and politics as developed in the disciplines of sociology, psychology, and economics. It draws upon comcepts and ideas taken from Game theory, and also scrutinizes the political layout of organizations.

The main political issues that emerge in conjunction with the organizational agenda are examined in the book. One chapter deals with the notion of "subjective politics," as it is perceived and described by internal participants and external observers. The book outlines the variety of political games that are played in the realm of organizations, listing nine types of games and specifies the ways in which individual level politics, group level politics, and organizational level politics take place. Power based, self-serving relationships between managers and executives are discussed under the title of "Managerial Politics" in chapter 10.

It should be noted that this volume deals with organizational politics and not with national or international politics. Broadly speaking, organization politics is here perceived as a power-based web of relationships conducted for the purpose of maximizing benefits. This is known in professional terminology as micropolitics, which frequently occurs in business corporations, factories, communal and governmental offices, hospitals and clinics, schools and universities, military and police organizations, communication networks and newspaper offices, art and cultural institutions, professional unions, voluntary associations, and many other organizations.

Those who participate in micropolitics may be individuals, groups, departments and organizational units, entire organizations or multi-organizational networks. In contrast with the wider scene of politics designated as macropolitics, organizational politics does not deal with political parties and factions. It is not the type of politics conducted according to socio-political points of view as declared in political party platforms. Moreover, active participants of micropolitics are executives, supervisors, workers, investors, clients and the like, who are neither politicians nor those whose main occupation is politics. As will be discussed in more detail, political behavior is in essence an informal, non-sanctioned, some times illegitimate, organizational behavior, which does not correspond to the rules and procedures of organizations.

The Political Agenda of Organizations should serve a variety of readers. It is intended mainly for students in the social and behavioral sciences as well as for students of business and/or public administration. It may assist lecturers and teachers who give courses on organization theory and the basics of organizational behavior. Managers, commanders, supervisors and officers can consult this book for an informal analysis of organizational structures and processes, such as budgeting and decision processes, from a political viewpoint. It can also serve as a tool for practitioners engaged in the management and development of human resources. Organizational consultants are likely to find in this 
volume some clues and directions for diagnosing organizations; reporters dealing with public and business organizations can obtain a better understanding of the organizational reality on which they report; public representatives who run governmental and municipal agencies can find a systematic and comprehensive analysis of organization politics in the institutions that they have been elected to govern. And the volume may also serve educated readers, who have an interest in the ways that organizations are run and in their influence on the daily life of the organizational society in which we live.

I have made every effort to write this book in a friendly manner and to address a large variety of readers, including readers who are unfamiliar with organization theory and who do not deal professionally with organizational research. It also contains a large selection of references published on this subject, which were used as source material for writing the book. In order to illustrate professional terms and abstract arguments, examples of different events that occurred in various countries were quoted from the media.

I view the writing of this book as a kind of payment of a debt to myself, and a tribute to the memory of my mentor and colleague-the late sociologist Robert (Bill) Hodge, who encouraged me to write a book on this subject at that early stage of my career.

\section{Note}

1. The present English volume is a translated and revised version of the original Hebrew book, The Political Game: Power and Influence in Organizations, published in Israel by The University of Haifa Press \& Zmora-Bitan, 2000. 


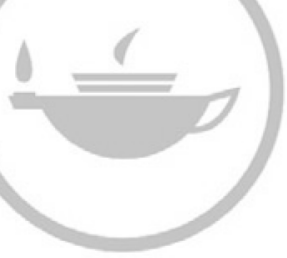

Taylor \& Francis
Taylor \& Francis Group http://taylorandfrancis.com 


\section{Introduction}

This introduction presents, in a condensed form, the conceptual and theoretical framework of organizational politics as it is discussed in the present volume. The emphasis in this brief chapter is on the introduction of a new theoretical approach to the study of organizations, which is intended to explain the pattern of political behavior of those participating in organizations and those who are in contact with them on the outside. The purpose of this theoretical framework is to provide a systematic analysis of the notion of political game in all its forms-a game that is conducted within organizations and among them.

Since the beginning of the twentieth century, the scientific effort to conceptualize the phenomenon of organizations has produced a series of paradigms, which have not yet been integrated into a general theory of organizations. Of the various perspectives on organizations, we shall focus briefly here on only two of them. The traditional view of organizations as rational systems ${ }^{1}$ sees them as merely "social machines" —designed and operated like instruments for the attainment of predetermined goals. ${ }^{2}$

Ideally, organizational participants are the operators of those machines, requested to perform their jobs and tasks as they are prescribed by formal rules, procedures, job descriptions, and contracts. From this perspective, members' informal actions and interactions are perceived to be unauthorized activities that do not accord with the regime of the organization. This outlook tends to underplay the role of the "human factor" and its effect on the behavior of organizations in general and that of their participants in particular.

Like any scientific theory, the rational theory is based on certain basic premises. Its primary assumption argues that every organization has a defined ultimate goal or mission, which justifies its existence in human society. Its secondary assumption postulates that organizations are well-controlled apparatuses, striving to fulfill their function. Organizations, therefore, define objectives and tasks, set procedures, and direct themselves in such a way as to proceed in the right direction - the way that will lead them to their ultimate goals. From this perspective, it is of no importance who was the individual or group that set the organization's goal, when it was set, and how; what is important is that the goal is a constant factor by which its inputs are determined and its outputs are assessed. 
According to this theoretical approach, organizations employ different means (such as job descriptions, contracts, rules, and procedures) to lessen uncertainty, to save resources, to set processes, to avoid arbitrariness and favoritism, to prevent friction and confrontations and to ensure the adoption of rational organizational decisions. In other words, to operate as effective and efficient machines targeted at a preset goal. Hence, the behavior of members in organizations is focused upon the good of the organization and is aimed at goal attainment.

Critique of the functionalist perspective in general and the rational theory in particular argues that it portrays a rather normative image of organizations that barely exist in real life. That is, it describes the best way to design and to manage organizations instead of explaining how they are actually built and operating. On the basis of this critique, a newer perspective in organization theory was advanced - known as the "critical perspective"-in which the "open system theory" was developed. ${ }^{3}$ This theory assumes that organizations are systems similar to many other systems in nature. However, organizations are social systems-namely, systems that are created and operated by human beings. From the moment they are created, these systems do the best they can to ensure their continued existence despite the forces that cause them to erode and disintegrate. According to this perspective, the goal of organizational systems of all types is merely survival.

Open systems ensure their existence through frequent exchange relationships with the surrounding environment in which they operate. In these exchange relationships, open organizational systems nourish the environment and are nourished by it. For this purpose they produce a series of valuable products and services and export them to the environment. At the same time, organizations import from their external environment the essential resources that ensure their continued existence and proper functioning. Hence, this approach renounces the existence of a preset goal or ultimate mission, and negates the importance of organizational goals as an essential component for understanding the structure and operation of organizations. Since this perspective attributes a high degree of egoism, sentimentalism, and impulsiveness to participants of organizations, it distrusts the assertion that they behave rationally from the organization's point of view.

"The political theory," which evolved within the framework of this intellectual approach to the study of organizations, views organizations as arenas for political struggles. In every organizational arena, human beings work alone or as groups to gain the best benefit that can be extracted from the organization with which they are involved. ${ }^{4}$ Thus, every stakeholder in this arena does have some objectives, ambitions, and goals of his own, which differ or even contradict those of other stakeholders in the organization. Therefore, in every organization there is an ongoing struggle over the organizational spoils between its competing stakeholders. Thus, "the political metaphor encourages us to see how all organizational activity is interest-based and to evaluate all aspects of 
organizational functioning with this in mind." Organizational survival is a result of the common goal of all stakeholders to preserve the organization and to continue gaining benefits from it. Scott explains this common interest:

One does not have to posit a survival need for the collectivity itself. It is sufficient to assume that some participants have a vested interest in the survival of the organization. Because it is a source of power, or resources, or prestige, or pleasure, they wish to see it preserved and include among their own goals that the organization itself be protected and, if possible, strengthened. ${ }^{6}$

The functional and the critical perspectives present two opposite views in respect to the way organizations should be perceived and studied. For the former perspective, organizational rationality serves as the key to an understanding of the structure and behavior of organizations; whereas for the latter perspective organizational politics is the main concept for understanding organizations and their dynamics. Both the rational theory and the political theory, like all the other theories that were developed in the area of organizations, are limited in their explanatory capacity and cannot fully cover the complexity of organizations. Therefore, a theoretical line of thought needs to be developed that combines the rational and the political aspects of the mutual relationships that exist in organizational life between individuals, groups, and organizations.

The theoretical line of thought suggested hereby is an attempt to broaden the political theory and to add some new elements to it, derived in part from the rational theory. This proposal, which is described here for the first time, will be called at this stage the theory of political shadows. Drawing upon the open system theory, this theory defines organizations as human productive systems that produce certain products or render specific services for the surrounding environment. This definition does not presume nor does it rule out the existence of an ultimate organizational goal, a final aim, a mission or some loftier purpose as a built-in feature of every organization. Organizations differ from other social systems, such as families or communities, by being productive systems: that is, systems that continuously produce goods or render services. The ultimate purposes that seemingly dictate the production of certain products or services in all organizations, if any do actually exist, are not essential for the understanding of the ways in which organizations are structured and operated. This is because organizations change again and again in their lifetime, as they attempt to adapt themselves to the many conversions that occur in the environments within which they exist and function.

Like any other theory, the theory of political shadows rests on several assumptions regarding the character of organizational activity in general and its actors' behavior in particular. ${ }^{7}$ The three basic assumptions of this theory can be noted as follows:

The organization-oriented assumption: This assumption states that, irrespective of personal inclinations, all participants in a given organization work according to the rules and regulations of the organization; hence, they comply with most of the orders and 
instructions of their supervisors and managers. Such functional behavior allows the organizations to accomplish their operational objectives, to advance their strategies, to produce goods and services, and to survive over time.

The self-oriented assumption: This assumption states that individuals join an organization and participate in its activities because it is their best alternative in terms of rewards and penalties. These individuals will continue to participate in that organization's activities as long as it is more profitable for them than participating in other organizations, or alternatively as self-employed actors. ${ }^{8}$

The benefit-oriented assumption: The third basic assumption states that actors in organizations use their power and influence over other actors in order to increase their own personal benefit above and beyond what is promised them in return for their activity, even if this political behavior is not regarded as appropriate in those organizations.

On the basis of these postulates, the main argument of the political shadows theory can be formulated as follows:

As a rule, for every organizational behavior there are two sides or faces: The official side which is manifested by compliance with the organizational rules and demands, and the unofficial side which is expressed by utilitarian behavior that exploits every chance to get the best for oneself. These two faces are linked together and complement each other. Thus, every official behavior, ${ }^{9}$ namely, behavior performed for the purpose of serving the organization, necessarily consists of unofficial behavior as well. The latter behavior is intended to benefit the individual performer or the person who instructs him to behave in this manner.

Because the official side is usually overt and the political side is covert, this dual behavior may be compared to a figure in the light, accompanied by a vague and obscure shadow. Just like any shadow, so the political shadow changes in its intensity and shape. Sometimes it is long, and sometimes short. In certain conditions of illumination it is strong and visible to the eye, and in other conditions it is too weak and pale to be noticed. Sometimes it is cast behind the object and sometimes alongside it. It takes the same shape as the figure, but yet distorts it to a greater or lesser degree.

Like the behavior of shadows in physical reality, so the political shadows in organizational reality change according to the conditions surrounding them. Organizational conditions and factors that influence the intensity and shape of political shadows are discussed in several chapters of this book.

The political shadows theory takes into account the existence of a structured tension between two types of rational behavior in organizations, that is, organizational rationality and personal rationality. The first type is expressed in the decisions and conduct of active members of the organization to promote the goals of the organization as a whole and to be concerned for its interests, while the second type is expressed by the behavior of active members of the organization whose purpose is to promote their goals, and satisfy their needs for their own personal interests. In many organizational situations the two be- 
haviors cannot coexist since they contradict each other. As a result, preference for one interest is liable to be at the expense of the other, thus creating a tension between the tendency toward conformism and the tendency toward opportunism in the behavior of members of an organization.

On the basis of these assumptions some general propositions may be posited now. The propositions may be later on examined empirically by a suitable research design. The following three hypotheses present typical examples of such theoretical propositions:

- Mutuality hypothesis: Given that a certain organizational activity is performed, there should be a positive relationship between the organization's benefit from this activity and the performer's benefit. That is, the more beneficial that activity is to the organization, the more beneficial it is expected to be for the performing actor as well. ${ }^{10}$ An unsatisfactory ratio between organizational utility and personal utility may increase the tendency of organizational actors to close this gap in favor of their own by means of self-serving political activities.

- Clarity hypothesis: It is expected that in obscure conditions and in illdefined situations in the organization, active members will adopt political behavior. Hence, situations of uncertainty, fuzziness, conflict and disagreement encourage the politicization of organizations, which is expressed in the propensity of organizational actors to exercise power, exert influence, and take political steps that will lead to clear decisions and to unequivocal definitions of responsibility and authority suitable to their priorities.

- Stability hypothesis: An increase in political behavior can be expected in organizations that encounter unstable conditions such as changes of status, decline, crisis or bankruptcy, that is, states in which the established system of rules in those organization are found to be in the process of disintegration. These are situations of transition in which the old order is no longer effective, and a new order has not been sufficiently established. These intermediate "liquidated" states encourage politicization, both because people do not know how they should behave and because people tend to take advantage of changing conditions for their own personal benefit before they miss the window of opportunity. ${ }^{11}$

It should be emphasized that from the present perspective, organizational politics is neither a marginal nor a negligible element of organizational reality - it is an inseparable part of it; hence, it deserves careful attention. By being interwoven within the organizational system and operating according to a certain code, it allows us to explain its place and role in this reality. The political 
shadows theory explains politics by using the concept of duality, which describes organizational behavior. This concept suggests that organizational behavior projects two conflicting propensities simultaneously: The first is the conformist propensity to obey the regulations of the organization, and the other is the opportunist propensity to exploit advantages for personal profit. This concept can be summarized in the following statement:

The Law of Political Calculation: Whenever an organizational actor is authorized or obliged to choose between several alternative actions for serving the organization, that actor is most likely to choose the alternative that best serves the actor's self interests and own preferences. This "law" foresees that organizational actors-individuals, groups, and organizations-will accomplish their tasks, but in a manner that suits them in the best way. This kind of behavior thus may prove to be optimal for its performer but not necessarily best one for the organization.

This book focuses upon the political behavior of individuals, groups, and organizations that are geared for self-benefit by exercising power and exerting influence over others. ${ }^{12}$

The first chapter in this book discusses in detail the concepts of power and influence as well as the causes and results of these phenomena in organizational activity.

The theory of political shadows serves as an analytical framework for the study of organizations from a political viewpoint. Such an analysis shows that even unselfish behavior patterns that are in line with the organization's interests, contain hidden political self-serving agendas. Moreover, under certain conditions, organizational behavior, that is by no means political, is likely to be interpreted by other actors inside or outside the organization as genuine types of political behavior.

This mode of analysis may shed equal light on both sides of organizational behavior: namely, it's formal as well as its informal faces. The book focuses on the opportunistic aspect of organizations, specifically because this aspect gets less attention than the conformistic aspect in the study of organizations. In addition to the scientific contribution of this line of analysis, the discussion about the political aspect may also be useful for various practitioners such as executives, commanders, and consultants who want to better understand the internal dynamics of the specific organizations that they attempt to influence.

\section{Notes}

1. Thompson, 1967.

2. See, for example, Morgan, 1986; Scott, 1992; Daft, 2001; Hall, 1999.

3. Katz \& Kahn, 1978; Scott 1992; Clegg, Hardy, \& Nord, 1996.

4. Bacharach \& Lawler, 1980; Pfeffer, 1981; Mintzberg, 1983; Morgan, 1986.

5. Morgan, 1986: 195.

6. Scott, 1992: 53.

7. The term "actor" in sociology means the individual, the group, and the organization that is actively involved in a defined social system and conducts mutual interactions with actors who take part in the same system. 
8. For a detailed discussion of this postulate see March \& Simon, 1958.

9. The professional term "official behavior" means dictated behavior that is officially and requisitely demanded from the participants in the organization by order of the organizational authorities. "Un official behavior"means behavior that is the result of the personal initiative of a participant that does not tally with the organization's policy.

10. See, for example, Kipnis \& Schmidt, 1988.

11. Mintzberg, 1985; Hardy, 1989.

12. The first chapter in this book discusses in detail the concepts of power and influence as well as the causes and results of these phenomena in organizational activity. 


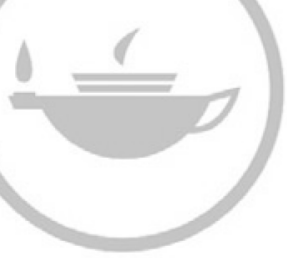

Taylor \& Francis
Taylor \& Francis Group http://taylorandfrancis.com 


\section{1 \\ The Essence of Power}

This book discusses organizational politics-namely, ways in which people work in different organizations and try to exercise influence upon organizational structures and processes as individuals or groups, in order to achieve specific results. In trying to understand how organizational politics works, it is necessary to study and to understand the phenomenon of power in social reality in general and in the organizational reality in particular. ${ }^{1}$ Hence, this chapter deals with the notion of power.

Power is one of the foundations of social life among the human species, as it is for other living creatures of all kinds. In nature, power is embodied in the physical prowess of animals. In human society it assumes many forms. Power is the motivating force that causes diverse types of behavior among individuals, groups, organizations, governments, and nations.

Bertrand Russell, the well-known philosopher, wrote about sixty years ago: "I shall be concerned to prove that the fundamental concept in social science is Power, in the same sense that Energy is the fundamental concept in physics." Since that time considerable intellectual effort has been expended on the part of social scientists in researching the roots of the power phenomenon in human society, and attempting to understand its dynamics and its implications for society and for social life. ${ }^{3}$ In the study of organizations, social scholars have dealt with the concept of power from various theoretical viewpoints. ${ }^{4}$

The efforts to explain the phenomenon of power created many different definitions of the power concept. These definitions revealed the conceptual differences among the various social sciences-psychology, sociology, political science, and economics-with regard to the phenomenon of power. Presumably these differences are the result of philosophical interpretations given by various intellectuals and humanists. Nevertheless, in spite of the differences between the definitions, certain commonly accepted components might be found that can characterize the power phenomenon. Moreover, many studies conducted on this subject over recent decades, brought forward a significant number of findings that can delineate the character of the power phenomenon in human society. Agreement is gradually being formed among researchers with regard to the essential nature of power, its sources, expressions, and results. 


\section{The Political Agenda of Organizations}

Therefore, it is appropriate to introduce some of the definitions of the concept of power and to discuss the ideas that they express. This is because power is the key to understanding the phenomenon known as "politics" in social life in general and in organizational life in particular.

Before we commence with the discussion it should be clarified that politics, in its broadest sense, includes all the actions aimed at gaining power and the usage of this power to attain goals and promote interests. The concept of power in politics has somewhat the same meaning as the concept of money in economics. Just as money turns the wheels of economics, so power turns the wheels of politics. ${ }^{5}$ Both power and money are valuable resources that are used as bargaining chips in conducting economic deals or political deals between actors. ${ }^{6}$

It is no wonder, then, that power and politics have been growing subjects of interest among students of organizations. In their preface to a recent volume of articles, Bacharach and Lawler refer to this trend:

As organizational politics began to emerge as a specific field of organizational theory some 50 years ago, many empirical studies were published that voiced implicit, if not explicit, political themes. We can look back to such classic works as Selzinck's TVA and the Grass Roots (1949), Gouldner's Patterns of Industrial Bureaucracy (1954), Crozier's The Bureaucratic Phenomenon (1964), Tannenbaum's Control in Organizations (1968), Zald's Organizational Change: The Political Economy of the YMCA (1970), Allison's The Essence of Decision (1971) and even Max Weber's prototypical Religion of China (1951) and clearly recognize the examination of organizations from an interest group perspective. ${ }^{7}$

\section{Concepts of Power}

"Power is the probability that one actor within a social relationship will be in a position to carry out his wishes despite resistance, regardless of the basis on which this probability rests." 8 This old and famous definition, suggested by Max Weber, is still used today with regard to most of the explanations of the power phenomenon. According to this definition, power is essentially coercion.

This view distinguishes power relationships from other social relationships as being asymmetrical in nature; that is, it deals with a situation in which one actor is capable of fulfilling his or her will in spite of the opposition of others to that will. Such coercion is achieved by the use of negative sanctions; that is, prevention of rewards or application of penalties upon noncompliance:" "Power in the present sense means control over rewards and/or penalties that give one actor, A, the capacity to induce otherwise unwilling compliance by a second actor, B."10

As it could be expected, this perception of power in social life raised various kinds of critiques and hence different conceptions of power. ${ }^{11}$ However, "This seemingly simple definition, which presents the negative rather than the positive aspects of power, has been challenged, amended, critiqued, extended, and rebuffed over the years but, nonetheless, remains the starting point for a remarkably diverse body of literature." 12 
Nonetheless, it is worth presenting here briefly some other views on the power phenomenon. For example, Harvey and Mills suggest expanding the definition of power so that it will include a larger scope of social relationships.

The definition of power with which we operate here is clearly much broader than this and is motivated by a felt need to conceptualize the general force resting behind all attempts to affect outcomes in social relationships, whether these attempts take the form of outright coercion, influence, or the exercise of legitimate authority. ${ }^{13}$

According to this approach, power is defined on the basis of two main factors: The first is the ability to use negative sanctions (penalties), and the other is the legitimacy (justification) for using power. By means of these two factors, Harvey and Mills distinguish between four types of power.

a. Legal Authority-Power that is based on a strong punishment capability and a high degree of legitimacy, that is to say, a willingness to comply because of a recognized, legally determined authority within a specific official framework.

b. Rational Authority - Power that is based on a weak punishment capability and a high degree of legitimacy, which expresses recognition of the expertise, knowledge, and experience of the person in power.

c. Coercion-Power that is based on a strong punishment capability for enforcing negative sanctions (penalties) and a low degree of legitimacy (repudiation).

d. Persuasion and Manipulation-Power that is based on a weak punishment capability and a low degree of legitimacy that is attributed to power and its usage. ${ }^{14}$

In many cases, power is based on the principle of deterrence. The ability of one actor to threaten another with negative sanctions saves him from the need to use his power. The expected negative response is the deterrent factor because of which the demands of the person in power are obeyed. Another aspect of deterrence ability results from the recognition of the fact that one actor possesses power over others in a given system of relationships. This knowledge also decreases the use of negative sanctions since this is also a deterrent factor that prevents resistance against the person in power, especially when this power is legitimized. Whenever there is a conflict between opposing desires of actors in a social relationship, the ability of one actor to overcome the will of the other is a practical expression of power.

The needs, motives, or goals of an actor are generally expressed in certain types of behavior. Persons, groups, and organizations usually tend to fulfill their needs by purposive, goal-directed actions. In the same way, social actors avoid, as much as possible, any behavior that goes against their needs, or behavior that makes it difficult for them to achieve their goals. From this perspective, power reflects a causal factor in human relationships that results in a change of behavior. Therefore, as Dahl suggests, "A has power over B to the 


\section{The Political Agenda of Organizations}

extent that he can get B to do something that B would not otherwise do."15 This definition perceives power as one's control of another's behavior.

Factors that increase the chances that an actor could cause another actor to change his behavior can be "structural factors" such as the role those actors hold in the organization, their place in the hierarchy of authority, or their centrality in the communication network of the organization. As it will be discussed in the chapter on interpersonal politics, there are different levels of power among people who take part in organizational activity compared with others in the organization. These differences result from their degree of proximity to the decision makers of the organization (for example a secretary or an assistant). Similarly, those who are close to centers of power in the external environment, such as government institutions or newspaper networks are likely to have greater power than those who are in remote positions.

Alternatively, factors that determine the power of actors may be psychological factors, that is, factors that are linked to the motivations of actors such as their ambitious drives or their domineering attitude. Power-driven people tend to recruit all their resources to gain power that will enable them to obtain positions of command and control. Persons identified as "politicians" are those actors striving to reach positions of dominance and who make every effort to hold those positions as long as possible.

Talcott Parsons, who treated power as a system resource, addressed a social system perspective of power; like money in economics, power operates as a specific mechanism responsible for creating change in individual or collective actors, interacting within a wider social system. Power is thus a means of coercion as well as consensus for the attainment of collective goals.

Power then is a generalized capacity to secure performance of binding obligations by units in a system of collective organization when the obligations are legitimized with reference to their bearing on collective goals and where in case of recalcitrance there is a presumption of enforcement by negative situational sanctions-whatever the actual agency of that enforcement. ${ }^{16}$

Michel Foucault contributes another conception of power in social life. From his point of view power should not be perceived as domination by one actor-individual, a group, a class or organization—over other actors. Power is never in any one's possession, since it is neither a commodity nor is it a certain kind of wealth. Instead, power is embedded in everyday details of normal life; it is mainly applied and enhanced by practices of surveillance-personal, technological, administrative, judicial, and so forth. Thus, power is accomplished by language, by cultural practices, by discourse, by moral, and by formal knowledge or expertise. By those means of control compliance becomes not only acceptable but to some extent even desirable.

Power must be analyzed as something which circulates, or rather as something which only functions in the form of a chain. It is never localized here or there.... Power is employed and exercised through a net-like organization. And not only do individuals 
circulate between its threads; they are always in the position of simultaneously undergoing and exercising this power. They are not only its inert or consenting target; they are always also the elements of its articulation. In other words, individuals are the vehicles of power, not its points of application. ${ }^{17}$

A different perspective, as presented by Hannah Arendt, sees the phenomenon of power as a communicative form of action. This conception makes a distinction between power, which rests on the common will of a group or population, and between force, which designates an individual property inherent in a person. Thus,

Power corresponds to the human ability not just to act but to act in concert. Power is never the property of an individual; it belongs to a group and remains in existence only as long as the group keeps together. When we say of somebody that he is "in power" we actually refer to his being empowered by a certain number of people to act in their name. ${ }^{18}$

Following the communicative interpretation of power, Mats Alvesson maintains that "the power element in communication means a forming and fixing of ideas, the selves of the participants and the preconditions for social interaction." ${ }^{\prime \prime}$ In other words, power is regarded as a dimension of cultural organizing, which influences ideas in such a way that it reinforces asymmetric relations between actors. ${ }^{20}$

The psychological perspective states that a concept of power has to include the element of intention to change the minds and behavior of others. Hence, the exercise of power towards another refers to "the capacity to produce intended effects, regardless of the physical or psychological factors on which the capacity rests." ${ }^{21}$ According to this approach, the person in power not only takes care to fulfill his intentions through influencing the behavior of others, but also deliberately prevents others from reaching their goals. ${ }^{22}$ This perspective emphasizes the subjective aspect and this heightens the complexity of power in social relationships.

Power is far too complex a phenomenon to be explained only by objective terms of causality or by subjective terms of intentions. Power has also to be examined as the ability to bring about certain results via intentional influence over others within an interactive relationship between specific actors. That is, power is the ability to influence that is created in certain social conditions and personal circumstances that occur at the same time. People who attain power of one type or another in circumstances for which they are not responsible, such as a sudden gain in wealth, could translate their power into practical influence over others only if they have the will to influence, the motive to change, or the desire to control.

The common term that appears in many definitions of power is that of ability. ${ }^{23}$ Ability refers to possible options and not necessarily to their actual implementation. Every actor who has certain capacities that enable him to enforce compliance over another actor enjoys a certain level of power over others. This 


\section{The Political Agenda of Organizations}

ability has two aspects: (1) the objective aspect, that is, power which is measured by the quantity and quality of resources of a specific actor with which he or she can influence another actor; and (2) the subjective aspect, that is, the assessment made by one actor about the ability of another actor to enforce his will over him or her in spite of resistance.

The definition of power relationships between actors in terms of causality leads the discussion to the concept of influence. It is already forty years since the two psychologists John French and Bertram Raven defined the term 'social influence' as the result expressed by "change in the belief, attitude or behavior of a person - the target of influence, which results from the action, or presence, of another person or group of persons-the influencing agent. Social power is thus defined as the potential for such influence. ${ }^{24}$

There are scholars who interpret the term influence as a general expression for all the means aimed at creating a change in the behavior of people. ${ }^{25}$ There are also those who distinguish between the term influence and the term authority, and others who differentiate between influence and coercion. ${ }^{26}$ According to this distinction, influence can be achieved by various means of persuasion: explanation, propaganda, preaching, and manipulation.

Power is created and used in organizational reality in the interactive relationships between various actors: individuals, groups, and organizations. In most cases these relationships are neither one-time encounters nor are they random. Therefore, power relations between actors usually occur in repetitious patterns of social exchange that are intended to achieve specific goals by the purposive use of various resources. These relationships are designated here as political games, and those who are active participants in those games are referred to here as players. ${ }^{27}$ These players are a part of a larger complex of interconnecting forces that form the "circles of power" in organizations. ${ }^{28}$

The success of the participants in these kinds of political games reflects their ability to bring about the results they desire; that is, to influence others into thinking and behaving in the way they want, especially in the process of decision making in the organization. Thus, the ability of an actor in any organization to influence an organizational decision in his favor despite opposition, expresses the power of that actor in the organization. As it will be seen in the following chapters, power plays a role in a large variety of relationships between individuals, groups, and organizations which are not necessarily connected to decision-making processes in organizations. This applies, for example, to power in a relationship between employees in an organization, or between two professional groups. In these cases, and in many other similar ones, the more powerful actor manages to force his will upon the weaker and to create a change of behavior in the latter.

The sample of definitions and interpretations briefly reviewed here indicates that the notions of power and influence are rather complex and subject to diverse interpretations. Additional treatments of power and influence illumi- 
nate these concepts from other viewpoints, raising questions and challenging various assumptions underlying them in which these social phenomena are conceptualized. ${ }^{29}$

\section{The Bases of Power and Its Sources}

In order that an actor may realize his ability to influence another, his power must rest upon a basis that is as solid as possible; that is, on an economic basis, a physical or military basis, a religious and ideological basis, and so on. This is an essential yet insufficient condition for the existence of power in a given relationship between two or more actors.

As it has been explained before, the effect of power depends on the ability of an actor to offer a reward of some kind in exchange for the compliance of another actor to his wishes, or by the ability of an actor to punish another in response to noncompliance. Therefore, the basis of any kind of power is contingent upon control over valuable resources that can benefit others, whether these resources are concrete (objects) or abstract (symbols). This control enables the empowered actor to adopt a political stance towards other peoplenamely, to employ inducements, to threaten penalties, to allow or deny access to resources, as well as to mislead those people.

Most students of power tend to classify the bases of power into different types in accordance with the classification introduced by French and Raven ${ }^{30}$ This classification distinguishes between five different bases upon which people build their power. Later on an additional basis was included. ${ }^{31}$

\section{Coercion}

This basis includes physical resources such as the physical power of a heavily built man, weapons and other combat means and control over armies and other armed forces. It enables the actor who holds this power to impose his will over another actor. The potential for destruction and killing of these resources and similar ones is used as a threat on the safety, and property, and even the life of others or of those dear to them. The term force describes this type of power in social relations. The beating of women and children, armed robberies, demand of protection money through threats on the safety and property of business people, cases of rape, and terrorist acts-all these are occurrences in which force is used to receive rewards, to protect interests or to maintain control over others through coercion.

The motive to comply when force is threatened or actually used is the fear of the negative outcome of noncompliance. Fear enables the person in power to impose his will upon others and force them to behave in the way he or she wants. This is exactly what a military occupation means. Certain criminal organizations, for example, are maintained by the collection of protection money through terrorizing businessmen and threatening to destroy their property. 


\section{The Political Agenda of Organizations}

\section{Rewards}

This power basis includes economic resources such as cash money, credit lines, securities, art treasures, and even assets such as buildings, equipment, and various installations. Such a basis allows the actor who owns the property to promise another actor some economic reward in exchange for compliance, or alternatively to delay the receipt of reward and even to withhold it from the other actor. The desire of people to receive financial rewards motivates them to perform illegitimate acts. Without these rewards it is doubtful if they would have performed such acts. ${ }^{32}$

Preferential treatment in return for bribes is one of the most widespread acts of corruption in government offices, municipalities, and other public institutes. False testimonies given in court, the leakage of classified information, slandering, spying and betrayal-all these are common examples of acts performed by people in exchange for rewards from the wealthy. Here the main motivation for compliance is the financial temptation. In the realm of organizations, too, one may find many examples of "gray" behavior on the borderline of the law. For instance, the appointment of a certain bank representative to a position on the board of directors of a business organization on the understanding that the bank will offer the organization a generous credit line or convenient payment conditions in exchange for the appointment.

\section{Expertise}

This basis includes information resources and experience in special fieldsresources that are usually based on long-standing professional expertise. Such resources are usually in the possession of academic professionals: doctors, lawyers, architects, psychologists, accountants, engineers, and other professional experts. In the recent past it was the artisans who had a predominant knowledge of the various fields of craftsmanship, and in the more distant past, this was the basis on which sorcerers, witch doctors, soothsayers, fortunetellers, and those of suchlike professions depended.

The social recognition of the professional talents of these experts allowed them to acquire power over those who needed their special services, very often in times of distress. As specialists, they could order their clients to change their habits, to adopt modes of thought and patterns of behavior other than the ones they were accustomed to follow. Although in most cases the exercise of power was intended to benefit the clients such as curing diseases, their expertise was sometimes used also to gain personal benefits for themselves at the expense of the clients. Price extortion, sexual bribery, the illegal acquisition of information, the enjoyment of excessive privileges, and receiving personal service - all these are quite common phenomena of the wrongful exploitation of information resources in exchange for favors in defiance of professional ethics. 


\section{Information}

This power basis presents one of the most important and valued resources of our times. Information is a commodity that is very much in demand nowadays. For many individuals as well as for most organizations, information is a critical resource for managing their affairs. At present, much more than in the past, every process of forecasting, planning, decision-making, and the like must rest on reliable information. An actor's access to required information gives him the opportunity to exercise power over other actors in need of it, with the intention of obtaining personal benefit. The more classified and rare the information is, the greater is the power of those who possess it. Therefore, it is no wonder that there are an increasing number of cases in which the 'information trade' motivates people to perform illegal and immoral acts, such as industrial espionage, in order to obtain information or to pass it on to others.

Sensitive information that affects privacy is usually found in the hands of doctors, lawyers, journalists, psychologists, and other such people. Professional ethics, and in certain cases even state laws, prohibits them from exposing this information. But classified personal information of this type is also found in our times in the possession of private investigators, of self-employed detectives, of usurers, of debt-collectors, and of the various kinds of intelligence services. For this reason, many people are subject to harassment, to intimidation, and even to blackmail by those who possess classified information about them, information that is sometimes acquired by questionable means. In such circumstances, those who possess the information are able to exercise their power over such people and to demand an exorbitant price, not necessarily in money, for their silence.

\section{Authority}

This power basis consists of the authorization granted to those holding positions of various kinds, especially in organizations, to exercise power over others. As opposed to other bases of power, this type of power is limited by definite constraints that restrict its quantitative and qualitative boundaries. In other words, authority is a power that may be used solely over specific actors, under precise conditions, in matters that are determined in advance, and with a limited use of rewards and penalties. Authority is attached to a specific officeit is not a personal trait or private possession of the person in office. Authority is a power that is granted legitimacy, which means it is given the prior consent of those subordinate to the person in authority to obey his/her instructions within a defined set of limitations, because that authority is an inseparable part of the office he or she holds. ${ }^{33}$

Since authority reflects not only ability but also legitimacy, it is often defined as legitimate power. In the organizational society of our time, authority is probably the most prevalent type of power. ${ }^{34}$ The expression "exceeding au- 
thority" relates to situations where a supervisor in an organization commands his subordinates to perform an action or to refrain from performing it without having the authority to give such commands. In many instances the exceeding of authority is motivated by personal considerations and the desire to gain personal benefit. The so-called sexual harassment is a typical example of illegitimate demand made by a senior officer to a junior one for the purpose of gaining personal benefits that exceed the privileges of the senior officer's authority.

\section{Charisma}

This basis of power represents extraordinary personal qualities, real or imaginary that some people attribute to a particular person in a particular society and in a particular period. The belief in the existence of qualities such as heroism, wisdom, resourcefulness, and foresight causes people to sympathize with those individuals who are regarded as unique and to comply with their demands. Power of this kind is usually identified with leadership. With this type of power as well, people tend to acknowledge a leader's authority in advance, and obey his every demand, usually without question or doubt.

In contrast to authority based on an organizational position, in the case of charisma the legitimacy is given not to the position of the leader but to the leader himself because of the personal qualities ascribed to him. On the basis of this power, many leaders in the course of human history have been able to impel millions of people to behave in ways that deviate from universal norms and to carry out actions that would not have been done without the leader's influence, actions such as robbery and plunder, expulsion and exile, murder and torture, and even mass genocide.

In spite of the repeated use of this classification of power bases, there are other researchers who prefer to make another kind of distinction that differentiates between power bases and power sources. ${ }^{35}$ However, it is doubtful if this additional distinction contributes to a better understanding of the concept of power. On the other hand, it is worth considering the following analysis that distinguishes between different sources of power in organizations-sources that originate from the characteristics of the organizations in which actors are to be found. ${ }^{36}$

\section{Certainty}

The ability of organizational actors (individuals, groups or organizational units) to reduce the level of uncertainty that the organization has to cope with is an important source of power. Uncertainty is an existential problem of organizations, which threatens their long-run survival. Hence, every solution that may help the organization to overcome uncertainty constitutes a source of power within it. The power of specialists, scientists, and similar experts, who closely interact with the organizational environment, lies in their capacity to decrease the amount of uncertainty that pervades in the organization. 


\section{Supply}

The ability of an organizational actor to supply the organization with the essential resources for its operation enables him to gain power. Since organizations are open systems, they are dependent upon the external environment. They therefore need to import various resources that are used as input for the production processes of goods and services. The acquisition of resources, some of them critical for the maintenance of the organization, involves rivalry, power struggles, the search for supply sources, high costs, and other difficulties. That is why every actor who can provide the organization with a necessary resource acquires real power in that organization. Investors, suppliers, consultants, and purchasers gain power in the organization, proportionate to their access to such sources of supply.

\section{Centrality}

The location of actor's communication networks, or along the flow of organizational work, is an important source of power to the organization to which he or she belongs. An actor located in the center of organizational work flow or at the center of the organization's communication network is capable of influencing the activities of other actors due to their dependence on him for performing their jobs. This power, therefore, is not dependent on the authority of those actors, because its source is in their structural location. Secretaries, executive assistants, telephone operators, and military signalers represent some examples of employees who are located at various centers of communication networks in organizations. Similarly, supervisors of computerized consoles controlling flow of work and material through production lines are located in central junctions in the flow of work of the organization. Nevertheless, in spite of their centrality, none of them possesses official authority that allows them to use the information for decision-making purposes of their own. What they do have is informal power derived from their central locations in the organization structure.

\section{Familiarity}

Organizational actors who are capable of correctly depicting the social landscape, and who know the important people of the organization, are likely to use this familiarity as a valuable source of personal power. Such actors possess social capital derived from their interpersonal relationships with influential figures, and they are therefore able to foresee the behavior of those influential figures in critical situations (such as in strategic decision-making processes or in management of crisis situations). For example, specialists in labor relations know how to identify the key people standing behind labor strikes, and to reveal their motives, with whom they are collaborating, and how and what would be the next steps taken by the representatives of the employers and of the 
employees in such circumstances. Such skills of those specialists as well as of similar experts serve as a good source of power.

\section{Reputation}

Organizational actors, who once wielded power, enjoy their reputation as a source of power in the present. People tend to credit others with specific characteristics that they formerly possessed long after they have lost them. Such attribution creates an image that after a time is accepted as a social fact even if it is already irrelevant. This tendency also occurs in situations where the reputation is attributed to groups or organizations, and it serves as a continuous source of power for them. In many countries, union leaders can be identified as people of great power because of their past combativeness, even though they have long ceased to lead the public and have stopped fighting its battles.

\section{Status}

The official position of a person in the hierarchy of authority of an organization is a source of power. The higher one's position is in the organizational hierarchy the more power he has. Although people holding senior positions at the top of the organization enjoy high levels of managerial authority, the personal power attributed to them often exceeds their authority. Junior employees are inclined to believe that senior staff members are "strong people" with much influence, even outside the organization. The general tendency is to believe that those people who managed to attain high positions use their organizational status for augmenting their own personal power and this enables them to enforce their will far beyond what their position allows. Hence, people in high organizational positions enjoy a feeling of power derived from their official status and not particularly from the authority that comes with it. This attitude of lower participants in organizations is directed not only towards senior managers and commanders, but also towards their assistants and secretaries, and their professional staff.

\section{Liability}

The ability of an organizational actor to offer benefits to others serves as a source of power in organizations. People who see themselves as indebted to an actor who has benefited them, grant him power by their very readiness to fulfill his wishes and to obey his demands. An actor who had considerably benefited others in the organization in the past can count on the gratitude accumulated towards him as a source of power, even in the present. This is a type of power that is possessed by those actors who have an influence over the hiring of workers, the nomination of positions in the organization, promotion in status and wages, and the granting of various emoluments. The feeling of liability towards them is their source of power in organizations. In many countries, civil executives and military commanders, chairmen of boards of directors, govern- 
ment ministers, and members of parliament as well as leaders of political parties depend on this source of power whenever they need to put their power to the test.

These sources of power are not restricted to individuals only; they are used as structural sources of power for organizational units of all kinds. They account for the relative and time-altered power of marketing and sales units, of computer centers and data management units, of research and development units, and of public relations units in organizations. They also explain the power of organizational units such as logistics, transportation, acquisition or maintenance, which enjoy a significant power, even though they are not in the mainstream of the organization. This power is obtained by their control over essential services for the functioning of the organization. From this perspective, one may understand the continuing power of organizations that have lost nearly all their other assets, a power that is based on a reputation that had been built up over the years.

\section{Expressions of Power and Its Symbols}

Power is frequently expressed by actors' modes of behavior towards others. Such behavior patterns can be overt and explicit, or covert and implicit, but they all have a common goal, which is above all to convey to the intended audience a message of power. By this message, the person in power intends to influence others to comply with his demands. Since these expressions are an inseparable part of the essence of power, it is appropriate to present them here.

\section{Threatening Actions}

The exercise of power in the relationships between actors usually includes the use of different types of resources. With regard to the person in power, the use of any resource is an expense, because resources tend to lose their value after they have been used. Hence, actors in power are inclined to save their resources and obtain their objectives through other means. The most common and, in many cases, the most efficient and decisive way is to make a threat against another person.

The threat is intended to make a clear stipulation between the behavior of a person and the expected outcome that will follow. A threat offers a choice between obeying and disobeying a certain demand, in such a way as to make it clear that noncompliance can result in the receipt of a prescribed penalty. Through the threat of imposing penalties on criminals, the state or municipal authorities ensure the compliance of the population to its laws. Many organizations behave in the same manner, formulating internal rules and regulations that oblige all their members, and that are accompanied by negative sanctions applicable in cases of noncompliance.

The most common expression for this type of stipulation is the "fine option." An offender knows in advance that he will have to pay a fine of some kind 
if he does not obey a certain law, unless he denies the offense in court. Threats may consist of a warning that benefits will be delayed or denied as a result of noncompliance. From the perspective of an actor who expects a certain reward (such as payment), every delay in receiving it is regarded as an act of punishment towards him. For example, in one industrial firm; the employees had imposed illegal sanctions and prevented the supply of goods to customers. In response, the chief executive officer threatened to delay salary payments. To prevent this threat from being carried out, hundreds of workers gathered one day in the management offices and laid siege to the bureau of the chief executive officer for many hours, damaged office equipment, and harassed him ceaselessly until he yielded and recalled his intention to delay salary payments.

In relationships between actors, a threat is expressed in two ways: (1) verbally, and (2) behaviorally. These two expressions of threat are quite common, both in interpersonal relations and in interorganizational relations, including relations between countries and world powers. For example, parents and teachers tend to use verbal threats towards children, especially when they are at a young age, such as: "If you do not behave properly, you will be punished by..." Official verbal threats, usually formulated in writing, are the working tools for lawyers who often use them on behalf of their clients. Heads of state use public verbal threats towards rival states, towards terror organizations, and towards various kinds of criminal organizations. Threats of this type are usually expressed in the form of a warning, not necessarily in diplomatic language. Business corporations usually make threats in the form of a declaration of intent to move their enterprises to other countries that would be more convenient and profitable for them. In the era of globalization, these are real threats from the point of view of professional unions, of tax authorities, and of the regional councils where the factories are located.

We have become increasingly aware of the fact that the effectiveness of an influence attempt, and the aftermath of influence, is a function not only of the basis of power but the mode, or manner, in which it is exercised. An influence attempt can be presented in loud, forceful, threatening, or sarcastic mode; or in a softer, friendlier, light-humored mode. The empirical evidence on the effects of mode is still quite limited, but there is good reason to expect that mode can be a very important component. Adolph Hitler was a master of presenting his coercive demands in a harsh, violent mode, adding emphasis to his threats. We have speculated that hard, sarcastic humor can sometimes increase the threatening quality in the use of coercion. It also appears at times that a clever influencing agent, who feels compelled to use coercion, will couple the coercive influence attempt with a light soft humor. This may avoid the negative and hostile aftereffects, and the undermining of referent and personal reward power, which may result from coercion. And there is, of course, evidence that effects of informational influence can sometimes be enhanced, sometimes reduced, if information is presented in a threatening or fear-invoking manner, as, for example, the use of a fear-appeal by a physician who attempts to convince a patient to stop smoking. ${ }^{37}$

Behavioral threats become explicit in certain actions that people with power apply in order to threaten others. Certain facial gestures, provocative poses, the 
display of fists, and the drawing of weapons, are only some of the varied actions that are easily recognized by human beings in most cultures as expressing a threat to act violently in case of noncompliance. In international relations, threats of this sort become explicit through the shifting of military forces, recruiting reserve soldiers, opening emergency depots, arming missiles, and conducting maneuvers near the borders that divide hostile countries. The United States, for instance, is accustomed to move its aircraft carriers, warships, and submarines in a demonstrative manner from their known and fixed locations at sea in order to threaten punitive action against "undisciplined" rulers like those of Libya, Iraq and Iran, North Korea, and other rulers in the wide world.

The practical test for any kind of threat is its level of deterrence. For the threat to really deter the person in question, the possessor of power must be prepared to carry out the threat as an act of punishment for noncompliance. In other words, the difference between a "true threat" and a "false threat" lies in the level of probability that the threat will be executed when required. During the first Gulf War, for example, the Israeli leaders threatened and warned publicly several times that if Iraq launched missiles against Israel, the IDF would respond with its full power and with a harsh counter-strike. The Iraqi ruler, Saddam Hussein, was not deterred by the Israeli threat and launched about forty missiles against Israel, which brought no military response in spite of the threats. From the Iraqi perspective, therefore, the Israeli threat was no more than a "false threat." As will be clarified later on, actors take into account the probability of the execution of the threats when deciding whether to comply or refuse to comply with the demands of rival actors.

\section{Penalty Actions}

The term penalty in the current context means any negative sanction that one actor applies to another in response to noncompliance. Negative sanctions include many different types of action that aim to harm resistant actors. Prominent among such negative sanctions are the following types of penalty:

Physical injury. These actions include intentional physical injuries such as beatings, different kinds of physical torture, imprisonment, starvation, and killing inflicted on others. Beating as a punishment for noncompliance is still common in society today among large numbers of husbands towards their wives and fathers towards their children. Until a few years ago, teachers and educators in different cultures used to beat pupils who had committed an offense-with a ruler, a stick, or a whip_-as a legitimate and educational act.

In various military organizations around the world it is common for military commanders to beat disobedient soldiers with a rifle butt as an act of punishment. Several years ago, there was a public uproar in the United States after a courthouse in Singapore sentenced an American student to be lashed for drugs found in his possession. In Asian and African countries it has been the practice for many years to truncate limbs and to physically mutilate law offenders. Even 
today there are several ethnic communities in which it is customary to execute moral offenders, especially "women who have desecrated their family honor." The execution of murderers and rapists is common today in several countries, including some states in America. It should also be noted that all governments around the world imprison criminals for lengthy periods. In the past, countries such as France, England, and Russia at one time banished criminals and political renegades to distant and desolate regions where living conditions were extremely difficult, such as Guinea, Australia, and Siberia.

In interorganizational and international relations there is a common tendency to hurt people physically as an act of punishment. Intelligence organizations tend to kidnap and secretly eliminate spies and traitors, assassinate rulers of other countries, and murder people they regard as instigators and rebels. The systematic elimination of those who plan terror attacks and carry them out is viewed by many people in the world as an act of punishment, not as a means to prevent terror attacks. The United States performed several penalty actions of destruction and killing against Libya, Iraq, Iran, Somalia, Sudan, and Afghanistan. These actions were mainly bomb attacks from the air and the sea and the launching of missiles at these countries. The United States' authorities had no compunction for capturing the former ruler of Panama, General Manuel Noriega, who had encouraged the smuggling of drugs, and did not hesitate to incarcerate him in an American prison for many years.

Economic injury. These actions generally take the form of monetary fines. Local and state authorities, civilian and military employers, academic institutions, leasing and renting companies, and moneylenders-all these and others usually impose fines as a penalty action for not respecting the law, for breaking a contract, or for disobeying the orders of superiors. The ability of an actorindividual or group--to impose a fine on another actor is an expression of power, which is proved when the fine is actually collected. Governments, municipalities, and local authorities that have failed to collect fines have lost power in the eyes of the public because they exposed their weakness and inability to enforce the laws and regulations in the area of their jurisdiction. This weakness is revealed once and again in various large cities all over the world, in which an enormous number of parking tickets are deliberately not paid by violators who take advantage of the difficulties of the law-enforcing authorities to collect the fines or to bring drivers to justice.

Another kind of economic injury that is inflicted in response to noncompliance takes the form of suspending the flow of funds or economic rewards. Shutting down credit lines, applying an economic blockade, closing off supply lines for goods, raising tariffs and limiting imports, the freezing of bank accounts and cancellation of financial contracts-all these represent some of the methods of this type of economic injury. The United States applies this kind of policy towards countries that they define as "rogue states" and terrorist organi- 
zations in order to "teach them a lesson." Among them are Cuba, the former Soviet Union, and the Republic of China at an earlier period, Libya, North Korea, Iran, Iraq, and others. All the Arab countries enforced an economic boycott against Israel for many years, and Egypt even blocked the passage of ships supplying goods to and from Israel through the Suez Canal. Israel conducted this kind of policy recently towards the Palestinian Authority in response to the rising terror attacks, acts of sabotage and shootings against Israeli citizens.

Business corporations apply explicit or implicit financial pressure on suppliers and contractors who do not live up to their expectations or upon those who give preference to their competitors. It is a known fact that wealthy parents sometimes deny their sons and their daughters financial means as well as legacies as punishment for behavior of which they do not approve. Associations and funds of all kinds also impose an economic ban on organizations that do not comply with their demands on issues such as environmental health, human rights and freedom, public health, and animal welfare. The difficulty inherent in the application of economic penalties of this type is in the need for it to be consistently upheld for a long period of time. Actors who apply economic penalties may soon discover that they have to change their policies as a result of internal or external pressure. Every enforced change of this kind damages the reputation of the powerful actors and decreases their actual power accordingly. The success of economic penalties depends, therefore, on the ability of the power holder (individual, group, organization or state) to maintain his or her policies of economic penalty for as long as necessary.

\section{Bribery Actions}

Many actors prefer the "carrot method" to the "stick method" when it comes to using their power to obtain compliance to their demands. Actions of this type are mainly expressed in two ways: temptation, and compensation. The carrot method is based on the offering of financial grants and other rewards which are of value and use to other actors who aspire to obtain them for themselves.

Temptation. One of the wittiest phrases on this subject is credited to the famous British dramatist, Oscar Wilde, who once said: "I can resist everything except temptation" (Lady Windermere's Fan, 1892). Most people obviously aspire to obtain more money and to increase the capital they possess. The financial motive impels people to commit actions that they would not have done if it were not for the financial profit promised to them in return for their behavior. Naturally, most people are willing to work for wages, salaries, or for other forms of remuneration. However, many people agree to engage in activities that are not respectable, such as the drug trade or prostitution, because they are tempted by a high financial reward. In extreme cases, the desire for profit leads to unusual acts such as surrender, treason, total commitment, self-abnegation, and abasement. 
It is therefore no surprise that many actors take advantage of human greed to exercise their power over them and to obtain their desires in this way. One of the most widespread and efficient methods of this type is the promise of a monetary bribe in exchange for compliance with certain demands that are illegal or immoral. Many employees of public and private organizations become targets for this type of temptation: in exchange for a bribe offered to them, people are asked to supply classified information (spying) or to give preferential treatment in appointments to desirable positions or in tenders for the supply of goods and services (favoritism). In other instances, they are asked to denounce their colleagues at work (slander), to spread false information in the organization (deception), or to mislead their employers (fraud). Quite naturally, the chances of response to this kind of temptation increase with the amount of money offered as bait.

The promise of a monetary bribe is one of the most widely used instruments employed by espionage organizations, by organized crime, drug dealers, and even by police organizations throughout the world. Monetary bribes are an inseparable part of the business dealings of corporations that function in Third World states in Africa, Asia, and Latin America. In many cases bribes are promised to government ministers, to senior officers, to judges, and to public representatives. Even the economic powers tend to offer poorer states enormous sums in exchange for compliance with their demands. The administration of President George W. Bush, for example, promised the Turkish government billions of U.S. dollars as economic aid if it would allow American forces to attack Iraqi targets from Turkish soil.

The greed for profit is a human weakness that exposes people to temptation by those who are wealthy. Lust is another weakness. And an additional temptation in exchange for cooperation is a "sex bribe." This very efficient means is serviceable for various actors--individuals, groups, and organizations-including respectable state organizations (for example, foreign offices and embassies of different countries) to influence certain people to comply with illegitimate demands imposed on them. It has been found that very often women who work in organizations have promised sexual favors to their superiors in exchange for professional advancements in status or salary. Generally speaking, sexual services are part of the reservoir of resources available to actors in human society and are used to gain power and to assist political maneuvers inside and outside organizations. In this connection, it is worth mentioning the success of some Islamic religious leaders in tempting impoverished and hotheaded youngsters to serve as suicide bombers in exchange for the promise of eternal life with many beautiful women in Paradise after their death as martyred heroes (shahid).

Compensation. The method of compensation is based on the payment of revenue, the granting of monetary awards, or the giving of any other kind of 
recompense in exchange for obedient behavior. The very granting of an award expresses power. It demonstrates the real ability of a certain actor to generously repay anyone who cooperates with his wishes. The greater the value of the compensation, the greater is the corresponding attributed power of the actor who grants it. Compensation of this type is frequently given without any explicit promises in advance. Unlike the method of temptation, compensation is only given retroactively to the person who cooperates.

The granting of monetary awards as a sign of appreciation to members of an organization for their devotion, hard work, and excellence is widely practiced everywhere nowadays. Many such awards express, in effect, the ability and desire of the employers and wealthy owners to give appropriate public honor for compliance with their interests. This is therefore a clear message of economic power. Indeed, private organizations grant significantly large monetary benefits to some of their employees, mostly to managers, whereas public organizations limit themselves to symbolic sums of money.

The foreign aid that the United States grants annually to Israel, Egypt, and Jordan-aid that amounts to large sums of money, food surpluses, military equipment, research and development funds, and economic guarantees-is one example of the compensation method employed by an economic power to the benefit of poorer countries that cooperate with its international policy. The Japanese government does this by means of investments and loans, while Germany prefers to grant economic benefits through valuable gifts such as civilian and military vessels, medical and educational establishments, and industrial enterprises.

Governments generally grant compensation to residents who agree to live in remote areas that are politically sensitive or subject to attack such as border settlements, regions of sparse vegetation, districts with scanty population, and so on. Such compensation is expressed by exemption from taxes and municipal rates, by special grants, by exceptional investments in the development of infrastructure and the promise of jobs and housing. All these are given to those residents in exchange for their cooperation with government policy and their support for the interests of the state by residing in such places. The many benefits granted over many years to the settlers in Judea, Samaria, and the Gaza Strip is one example of the "carrot method" form of economic compensation. Other examples can be found, of course, in other countries.

\section{Symbolic Expressions}

Similar to symbolic expressions of social status, social power is also frequently expressed by demonstrative symbols. The symbols of power are an indispensable part of the political language through which political discourse takes place in various social frameworks, including different types of organizations.

Political language enables the assignment of appropriate meaning to political activities so as to become legitimate and thus acceptable to members of a 
given social system. Such justification allows the actors who possess power to enlist support for their decisions and actions and to buttress their power. Political language also helps to undermine the status of rival actors and to raise doubts as to their power. Words and phrases can be used as weapons in political struggles and as supplemental means to gain influence over the thoughts, emotions, and behavior of others.

Symbolic objects and behaviors also constitute part of the overall expressions of power and the political use made of them to achieve desirable goals. Due to their hierarchical and formal nature, most organizations make extensive use of power symbols for the purpose of creating a clearly established distinction among their participants.

The provision of social actors with the symbols of power both ratifies their power position within the organization and provides them with power because of the symbols. In a situation in which social power may be difficult to assess, the provision of clear signals of power conveys to others the fact that social actors who possess these symbols have come to be valued and revered in the organization. This social definition of power becomes, through its physical manifestation in the form of symbols, a shared reality, which serves to convey power to those possessing the symbols. ${ }^{38}$

The use of title and rank, by a special term, method of address, salute, bow, nod of the head, and kiss of the hand, are some of the of verbal and bodily expressions of submission towards powerful people that are practiced in different cultures. Power holders take great care in demonstrating their power through both official and non-official symbols.

Throughout history, it was the practice for kings, rulers, military commanders, religious leaders, and other men of authority to decorate themselves with rank insignia, badges, special dress (such as uniforms, robes, crowns, helmets), with staffs and batons, jewelry (such as rings and bracelets), and with other trappings for the purpose of symbolizing their power to the ruled population. Ever since recorded time, those in power have resided in palaces, castles, and luxurious mansions, surrounded by walls and guards. The use of special vehicles (splendid carriages, official cars, private trains and airplanes) was also meant for the same purpose. The well-known excuse for using such symbols is the importance of the personal safety of these superior personages. In fact, all these practices represent some of the side benefits and the perks that these power holders enjoy.

In the different kinds of contemporary organizations, it is customary to symbolize the power of managers and executives by the size, location, and luxury of their offices, by their reserved parking lots, by private dining halls, and even by their exclusive restrooms. These symbolic expressions concretely emphasize the hierarchy of authority in the organization and the location of each actor in the rungs of power. This system of symbols is consistently applied in various subunits within the organization: divisions, departments, sections, and the like. The location of each of these units in the organizational compound, 
the size of the area assigned to each of them, the number of floors, and the luxury standard of the buildings and installations in which the workers are placed - all these symbolize their proportionate power in the organization. Even if this geographical layout cannot change at the same rate as the changes in the balance of power within the organization, it still constitutes part of the political discourse in organizations. ${ }^{39}$

Many countries demonstrate their power through military marches in which they display their sophisticated armaments, or by airplane fly-bys and naval vessels sailing by in procession. Another way for the symbolic demonstration of technological and economic power is participation in various international exhibitions where countries show off their best products. Even in world sport competitions, such as the Olympics Games or the World Cup, there are symbolic expressions of power-personal, educational, and cultural-in which many countries differentiate themselves from the others.

Business organizations, mainly the biggest and richest of them, occasionally hold extravagant displays of their products to a select invited audience, not necessarily from among its clients. Such displays are accompanied by lavish meals, cocktail parties, granting of gifts, arranging of organized tours, and so on. Beyond the business objectives of these events, there lies the hidden agenda of the organizations to demonstrate their economic strength and political power. Even the support for artistic and educational activities, the public funding of parks and outdoor statues, and other acts of charity, carry a symbolic meaning, which is to display for the public the power of the organization.

Some of the symbolic expressions of power are those of the social establishment, that is, symbols and ceremonies that are identified among the general public and accepted by most people as symbols of legitimate power. These consist, for example, of things such as pistols, truncheons, handcuffs hung on the belts of police officers. But there are also other symbols of power whose significance is not generally known to all, because they are incorporated within a certain subculture-for example, symbols of power that are common among criminal gangs, religious sects, or secret orders.

To sum up, in spite of the differences between the various symbols of power, all are intended to indicate to the other that the power holder is liable to use his power as needed in order to enforce his authority. Symbols of power serve, therefore, as deterrent mechanisms against rejection, opposition, rebellion, and complaint. $^{40}$

\section{Conclusion}

The phenomenon of power holds a central position in social life everywhere. This form of energy takes many alternating forms in human society, and serves as a preventive force against numerous actions both at the level of individual and group behavior and at the level of all types of organizations. Therefore, actors of all kinds seek to amass power and tend to use it to acquire 
personal benefit, to derive something of value, and to gain control over others. It is no wonder, then, that power struggles are an important component in the system of relationships between social actors, both for individuals and for groups. The relations between parents and children, teachers and pupils, those in charge and those subordinate to them, all involve a continual challenge to acquire power and to employ it.

The study of power that has been conducted mainly in the twentieth century has produced many definitions and interpretations, none of which have been equally accepted among scholars. Nevertheless, there are some characteristics of the power phenomenon that allow for an understanding of its essential nature and its use in order to explain various social phenomena. These characteristics have been described and illustrated in this chapter.

Most of the definitions of the power concept see power first and foremost as ability, possibility or potential. Power is therefore the possibility afforded the actor to realize his wishes by means of others and to obtain the results he desires, even if the other shows resistance to it. According to this conception, power exists even when it is not actually exercised. This potential creates a causal connection between the behavior of social actors within given conditions.

Power is revealed in various forms in social life. One of the forms of power is physical coercion; another is authority acquired through its legitimacy; and a third form is deceit, obtained through misleading the other. Whatever the form, power acquires practical expression through the degree of influence it has on others, that is, in its very achievement of the goals for which it is exercised.

Power depends on a number of basic factors and is derived from several sources. The basic elements of power are the various resource reservoirs that actors control or have access to. These basic elements include physical resources, economic resources, and knowledge resources, resources of ideas, personal resources, and information resources. As we shall see in the following chapters, each type of resource enables its possessor to take the political steps aimed at influencing others to behave in the manner desired by the power holder in specific circumstances.

In various social frameworks, such as in different kinds of organizations, structural and existential problems are created that have no tested and prescribed solution. In such circumstances, those actors who are capable of supplying suitable solutions or assist in finding them will acquire power. This is the case also for actors who attain key positions in production processes, in the communications network, and in the role assignment system of the social frameworks within which they play an active part. These circumstances constitute sources of power from which the actors derive their ability to influence the decision-making processes and their results.

With the aim of successfully influencing their intended actors, the power holders perform various actions and activate a variety of means with the pur- 
pose of expressing the full weight of their power in an open and clear manner. These expressions of power include verbal and behavioral threats, penalty actions both physical and economic, temptations through the promise of benefits, and the granting of compensation and awards. Such expressions highlight the power of those in authority, helping them to enlist support for their position and activities, and make it easier for them to fight against those who oppose them inside or outside the organization.

In organizational reality, power serves as the main resource through which individuals, groups, and organizations can participate in power struggles of various kinds that are identified in this book as "political games." This indicates that power constitutes the main exchange means that social actors employ in organizational politics in order to derive the greatest possible value from their participation in the organization and from their investments in it. This value implies the obtaining of more rights, benefits, assurances, advantages, and pleasures than they are entitled to receive, if at all, by virtue of official regulations and contracts. Therefore, the political shadows that accompany most of the behavior of organizational actors are the key to understanding organizational dynamics and to interpreting the power struggles that are conducted among the various parties concerned within organizational reality.

\section{Notes}

1. The term "power" is not identical with the word "force," although many people err in using these words as though they were synonyms. The difference between these terms will be clarified and emphasized in various chapters of this book.

2. Russell, 1938: 18.

3. See, for example, Mills, 1956 ;

4. See, for example, Weber, 1947; Cyret \& March, 1963; Thompson, 1967; and Pettigrew, 1973.

5. For a detailed comparison of the role of money in economics and that of power in politics, see Parsons, 1963.

6. The term "actor" is used in sociology to define individuals, human groups, organizations of all kinds and business corporations, states, and international institutions (such as the United Nations) which constitute clearly defined entities that conduct interactive relationships with other actors.

7. Bacharach \& Lawler, 2000: ix.

8. Weber, 1947: 152.

9. Blau, 1964.

10. Samuel \& Zelditch, 1989: 288

11. For a collection of articles presenting different interpretations of power, see Lukes, 1986.

12. Hardy \& Clegg, 1996: 623.

13. Harvey \& Mills, 1970: 202-203.

14. Harvey \& Mills, 1970: 203.

15. Dahl, 1957: 201.

16. Parsons, 1963b.

17. Foucault, in Lukes, 1986: 234.

18. Arendt, 1970: 44. 


\section{The Political Agenda of Organizations}

19. Alvesson, 1996: 3.

20. On the communicative perspective of power, see also Habermas, 1984.

21. Wrong, 1996: 22.

22. Bates, 1970.

23. The ancient Latin root of the word "power" (in French pouvoir) is posse which means "to be able."

24. Raven, 1992: 218.

25. For example: Tedeschi \& Bonoma, 1972; Wrong, 1996.

26. See, for example, Bacharach \& Lawler, 1980.

27. Chapter 6 in this book is devoted entirely to the description and classification of political games in organizational life.

28. Clegg, 1989.

29. See, for example, Bachrach \& Baratz, 1962, 1970; Goldman, 1972; Lukes, 1974; Clegg, 1979, 1989; Galbraith, 1983; Boulding, 1989; Reed, 1989; Nicolson, 1996; Gergen, 1999; Gabriel, Fineman \& Sims, 2000; Weick, 2001.

30. French \& Raven, 1960.

31. Raven, 1992.

32. It is unnecessary to note that many people choose to perform actions that are desirable and useful to society not only because of the benefits they derive from them, but also because of monetary inducements without which they would not be prepared to act. The entry of idlers into the work force, the rehabilitation of drug addicts, the reformation of criminals, and the agreement of rapists to undergo medical treatment are some of the examples of the influence of monetary rewards on the drastic changes in deviant behavior patterns.

33. Samuel, 1996: 107-132 (Hebrew).

34. It is worth noting here that among the researchers there are those that distinguish between the concept of power and the concept of authority, and between that and the concept of persuasion, since in their view these concepts represent three separate phenomena that are expressed in different ways in social life. See the discussion on these distinctions and the bibliographical references in Samuel \& Zelditch, 1989.

35. See this kind of differentiation in Bacharach \& Lawler, 1980.

36. Pfeffer, 1997: 145-146.

37. Sutton 1982, quoted in Raven, 1992: 223.

38. Pfeffer, 1981: 54.

39. Pfeffer, 1981.

40. Samuel \& Zelditch, 1989. 


\section{References}

Acker, J. 1990. "Hierarchies, hobs, bodies: A theory of gendered organizations." Gender and Society, 4, 139-158.

Alker, H. 1973. "On political capabilities in schedule sense: Measuring power, integration, development," pp. 307-373, in H. R. Alker, K. W. Deutch, and A. H. Stoezel (eds.), Mathematical Approaches to Politics. Amsterdam: Elsevier Scientific Publishing.

Astley, W. G., and P. S. Sachdeva. 1984. "Structural resources of intraorganizational Power: A theoretical synthesis." Academy of Management Review, 9, 104-113.

Allen, M. P., D. L. Madison, L. W. Porter, P. A. Renwick, and B. T. Meyes. 1979. "Organizational politics: Tactics characteristics of its actors." California Management Review, 22, 77-83.

Allison, J. T. 1971. Essence of Decision. Boston: Little, Brown.

Alvesson, M. 1996. Communication, Power and Organization. Berlin: Walter de Guyter.

Arendt, H. 1970. On Violence. New York: Harcourt, Brace \& World.

Axelrod, R. M. 1970. Conflict of Interest: A Theory of Divergent Goals. Chicago: Markham.

Bachrach, P., and M. S. Baratz. 1962. "The two faces of power." American Political Science Review, 56, 947-952.

Bachrach, P., and M. S. Baratz. 1970. Power and Poverty. London: Oxford University Press.

Bacharach, S. B., and E. J. Lawler. 1980. Power and Politics in Organizations. San Francisco: Jossey-Bass.

Bacharach, S. B., and E. J. Lawler (eds.). 2000. Organizational Politics: Research in the Sociology of Organizations, vol. 17. Stamford, CT: JAI Press.

Barley, S. R. 1991. "Contextualizing conflict: Notes on the anthropology of disputes negotiation," pp. 165-202, in M. H. Bazerman, R. J. Lewicky, and B. H. Sheppard (eds.), Research on Negotiation in organizations. vol. 3. Greenwich, CT: JAI Press.

Barley, S. R. 1988. "Technology, power, the social organization of work: Towards a pragmatic theory of skilling deskilling." Research in the Sociology of Organizations, 6, 33-80.

Bates, F. L. 1970. "The political-economy approach in retrospective," pp. 262-269, in M N. Zald (ed.), Power in Organizations. Nashville: Vanderbilt University Press.

Benson, J. K. 1975. "The interorganizational network as a political economy." Administrative Science Quarterly, 20, 229-249.

Berger, J., and M. Zelditch, Jr. 1998. Status, Power, and Legitimacy. New Brunswick, NJ: Transaction Publishers.

Biddle, B. J., and E. J. Thomas. 1966. Role Theory: Concepts Research. New York: Wiley.

Bierstedt, R., 1950. "An analysis of social power." American Sociological Review, 15, 730-738.

Bierstedt, R. 1974. Power Progress: Essays on Sociological Theory. New York: McGraw-Hill.

Blalock, H. M., Jr. 1989. Power Conflict: Toward a General Theory. Newbury Park: Sage. 
Blau, P. M. 1964. Exchange Power in Social Life. New York: Wiley.

Boeker, W. 1992. "Power managerial dismissal: Scapegoating at the top." Administrative Science Quarterly, 37, 400-421.

Boulding, K. 1989. Three Faces of Power. Newbury Park, CA: Sage.

Brass, D. J. 1984. "Being on the right place: A structural analysis of individual influence in an organization." Administrative Science Quarterly, 29, 518-539.

Brass, D. J., and M. E. Burkhardt. 1993. "Potential power in use: An Investigation of structure behavior." Academy of Management Journal, 36, 441-470.

Bura, A. 1986. Social Foundations of Thought Action: A Social Cognitive Theory. Englewood Cliffs, NJ: Prentice Hall.

Burawoy, M. 1985. The Politics of Production. New York: Verso.

Burt, R. S. 1980. "Cooptive corporate actor networks: A reconsideration of the interlocking directorates involving American manufacturing." Administrative Science Quarterly, 25, 557-582.

Burns, T. 1961. "Micropolitics: Mechanisms of institutional change." Administrative Science Quarterly, 6, 257-281.

Cialdini, R. B. 1988. Influence: Science Practice, 2nd ed. Glenview, IL: Scott, Foresman.

Clegg, S. R. 1975. Power, Rules and Domination. Boston: Routledge and Kegan Paul.

Clegg, S. R. 1979. The Theory of Power and Organization. London: Routledge and Kegan Paul.

Clegg, S. R. 1989. Frameworks of Power. London: Sage.

Clegg, S. R., C. Hardy, and W. R. Nord (eds.). 1996. Handbook of Organization Studies. London: Sage.

Cobb, A. T. 1984. "An episodic model of power: Toward an integration of theory research." Academy of Management Review, 9, 482-493.

Cohen, I. and R. Lachman. 1988. "The generality of the strategic contingencies approach to sub-unit power." Organization Studies, 9, 371-391.

Coleman, J. S. 1973. "Loss of power." American Sociological Review, 38, 1-17.

Cook, K. S. 1977. "Exchange and power in networks of interorganizational relations." Sociological Quarterly, 18, 62-82.

Cook, K. S., and R. Emerson. 1978. "Power, equity, and commitment in exchange networks." American Sociological Review, 43, 712-739.

Coser, L. A. 1976. "The notion of power: Theoretical Developments," pp. 150-161, in L. A. Coser and B. Rosenberg (eds.), Sociological Theory: A Book of Readings, $4^{\text {th }} \mathrm{ed}$. New York: Macmillan.

Cropanzano, R., J. C. Howes, A. A. Grey, and P. Toth. 1997. "The relationship of organizational politics support to work behaviors, attitudes, stress." Journal of Organizational Behavior, 18, 159-180.

Crozier, M. 1964. The Bureaucratic Phenomenon. Chicago: University of Chicago Press.

Cyret, R. M., and J. G. March. 1963. A Behavioral Theory of the Firm. Englewood Cliffs, NJ: Prentice-Hall.

Czarniawaska-Joerges, B. 1992. Exploring Complex Organizations: A Cultural Perspective. Newbury Park, CA: Sage.

Daft, R. L. 2001. Organization Theory and Design, $7^{\text {th }}$ ed. Cincinnati, OH: South-Western College Press.

Daft, R. L. 2004. Organizations: Theory and Design. $8^{\text {th }}$ edition. Mason, OH: Thompson.

Dagan-Nissim, D. 1997. "Professional and political considerations in rendering in-house service." Master's thesis, The Technion--Israel Institute of Technology, Haifa (Hebrew).

Dahl, R. 1957. "The concept of power." Behavioral Science, 2, 201-215.

Dalton, M. 1959. Men Who Manage. New York: Wiley. 
Drazin, R., and R. Hayagreeva. 1999. "Managerial power succession: SBU managers of mutual funds." Organization Studies, 20, 167-196.

Drory, A., and T. Romm. 1988. "Politics in organization its prevention within the organization." Organization Studies, 9, 165-179.

Drory, A., and T. Romm. 1990. "The definition of organizational politics." Human Relations, 11, 1133-1154.

Edelman, M. 1964. The Symbolic Uses of Politics. Urbana, IL: University of Illinois Press.

Eisenhardt, K. M., and L. J. Bourgeois III. 1988. "Politics of strategic decision making in high-velocity environments: Toward a midrange theory." Academy of Management Journal, 31, 737-770.

Emerson, R. M. 1962. “Power-dependence relations.” American Sociological Review, 27, 31-41.

Emerson, R. M. 1972. "Exchange theory," Part I, Part II," pp. 38-88, in J. Berger, M. Zelditch and B. Anderson (eds.), Sociological Theories in Progress, vol. 2. Boston: Houghton Mifflin.

Enz, C. A. 1988. "The role of value congruency in intraorganizational power." Administrative Science Quarterly, 33, 284-304.

Etzioni, A. 1975. A Comparative Analysis of Complex Organizations. $2^{\text {nd }}$ ed. New York: The Free Press.

Etzioni, A. 1988. The Moral Dimension: Towards a New Economics. New York: Plenum Press.

Falbe, C. M., and G. Yukl. 1992. "Consequences for managers of using single influence tactics combinations of tactics." Academy of Management Journal, 35, 638-652.

Ferris, G. R., D. B. Fedor, J. C. Chachere, and L. R. Pondy. 1989. "Myths politics in organizational context." Group Organization Studies, 14, 83-103.

Ferris, G. R., and K. M. Kacmar. 1992. "Perceptions of organizational politics." Journal of Management, 18, 93-116.

Ferris, G. R., D. D. Frink, M. C. Galang, J. Zhou, and J. L. Howard. 1996. "Perceptions of organizational politics: Prediction, stress-related implications, outcomes." Human Relations, 49, 233-266.

Finkelstein, S. 1992. "Power in top management teams: dimension, measurement, validation." Academy of Management Journal, 35, 505-538.

Fligstein, N. 1987. "The intraorganizational power struggle: The rise of finance presidents in large corporations, 1919-1979." American Sociological Review, 52, 44-58.

Foucault, M. 1984. A History of Sexuality. London: Peregrine.

Foucault, M. 1986. “Disciplinary power and subjugation," pp. 229-242, in S. Lukes (ed.), Power. Oxford, UK: Basil Blackwell.

Fredrickson, J. W. 1992. "A model of CEO dismissal.” Academy of Management Review, $13,255-270$.

French, J. R. P., Jr. and B. Raven. 1960. "The bases of social power," pp. 607-623, in D. Cartwright and A. Zender (eds.), Group Dynamics, 2nd ed. New York: Harper and Row.

Gabriel, Y., Fineman, S. and D. Sims. 2000. Organizing and Organizations, $2^{\text {nd }}$ ed. London: Sage.

Galbraith, J. K. 1983. The Anatomy of Power. Boston: Houghton Mifflin.

Gamson, W. 1968. Power Discontent. Homewood, IL: Dorsey.

Gandz, J., and V. V. Murray. 1980. The Experience of Workplace Politics. Academy of Management Journal, 23, 237-251.

Gargiulo, M. 1993. "Two-step leverage: Managing constraint in organizational politics." Administrative Science Quarterly, 38, 1-19.

Gergen, K. J. 1999. An Invitation to Social Construction. London: Sage. 
Gils, M. R. 1984. "Interorganizational relations networks," pp. 1073-1100, in P. J. D. Drenth and B. Groenendijk (eds.), Handbook of Work Organizational Psychology, vol. 2. New York: Wiley.

Goldhamer, H., and E. A. Shils. 1939. "Types of power status." American Journal of Sociology, 45, 171-182.

Goldman, A. I. 1972. "Towards a theory of social power." Philosophical Studies, 23, 221268.

Goldner, F. H. 1970. “The division of labor: Process of power," pp. 97-143, in M. N. Zald (ed.), Power in Organizations. Nashville: Vanderbilt University Press.

Gouldner, A. W. 1954. Patterns of Industrial Bureaucracy. New York: Free Press.

Granovetter, M. 1985. "Economic action social structure: The problem of embeddedness." American Journal of Sociology, 91, 481-510.

Gulati, R., and M. Gargiulo. 1999. "Where do interorganizational networks come from?" American Journal of Sociology, 104, 1439-1493.

Habermas, J. 1984. The theory of Communicative Action. Vol. 1. Boston: Beacon Press.

Hackman, J. D. 1985. "Power centrality in the allocation of resources in colleges universities." Administrative Science Quarterly, 30, 61-70.

Hambrick, D. C. 1981. "Environment, strategy power within top management." Administrative Science Quarterly, 26, 253-276.

Hardy, C. 1989. Strategies for Retrenchment Turnaround: The Politics of Survival. New York: deGruyter.

Hardy, C., and S. R. Clegg. 1996. "Some dare to call it power," pp. 622-641, in S. R. Clegg, C. Hardy, and W. R. Nord (eds.). 1996. Handbook of Organization Studie. London: Sage.

Hardy, C., and N. Phillips. 1998. "Strategies of engagement: Lessons from the critical examination of collaboration conflict in interorganizational domain." Organization Science, 9, 217-230.

Harpaz, I., and I. Meshoulam. 1997. "Intraorganizational power in high technology organizations." Journal of High Technology Management Research, 8, 107-128.

Harsanyi, J. C. 1962. "Measurement of social power, opportunity costs, and the theory of two-person bargaining game." Behavioral Science, 7, 67-80.

Harvey, E., and R. Mills. 1970. "Patterns of organizational adaptation: A political perspective," pp. 181-213, in M. N. Zald (ed.), Power in Organizations. Nashville: Vanderbilt University Press.

Haunschild, P. A., and C. M. Beckman. 1998. "When do interlocks matter? Alternate sources information interlock influence." Administrative Science Quarterly, 43, 815844.

Henderson, A. H. 1981. Social Power. New York: Praeger.

Hickson, D. J., C. R. Hinings, C. A. Lee, R. E. Shneck, and J. M. Pennings. 1971. "A strategic contingencies theory of intraorganizational power." Administrative Science Quarterly, 16, 216-229.

Hickson, D. J., J. W. Astley, R. J. Butler, and D. C. Wilson. 1981. "Organization as power," pp. 151-196, in L. L. Cummings, B. M. Staw (eds.), Research in Organizational Behavior, 3. Greenwich, CT: JAI Press.

Hinings, C. R., D. J. Hickson, J. M. Pennings, and R. E. Shneck. 1974. "Structural conditions of intra-organizational power." Administrative Science Quarterly, 19, 22 44.

Hinkins, T. R., and C. A. Schriesheim. 1990. "Relationships between subordinate perceptions of supervisor influence tactics attributed bases of supervisory power." Human Relations, 43, 221-237.

Homans, G. C. 1974. Social Behavior: Its Elementary Forms. New York: Harcourt Brace Jovanovich. 
Ibarra, H., and S. B. Andrews. 1993. "Power, social influence, sense-making: Effects of network centrality proximity on employee perceptions." Administrative Science Quarterly, 38, 277-303.

Kahn, R. L., D. M. Wolf, R. P. Quinn, J. D. Snoek, and R. A. Rosenthal. 1964. Organizational Stress: Studies in Role Conflict Ambiguity. New York: Wiley.

Kanter, R. M. 1977. Work and Family in the United States: A Critical Review and Agenda for Research and Policy. New York: Russell Sage.

Katz, D., and R. L. Kahn. 1978. The Social Psychology of Organizations, $2^{\text {nd }}$ ed. New York: Wiley.

Kipnis, D., S. M. Schmidt, and I. Wilkinson. 1980. Intraorganizational influence tactics: Explorations in getting one's way." Journal of Applied Psychology, 65, 440-452.

Kipnis, D., and S. M. Schmidt. 1983. "An influence perspective on bargaining within organizations," pp. 302-319, in M. H. Bazerman, R. J. Lewicki (eds.), Negotiating in Organizations. London: Sage.

Kipnis, D., and S. M. Schmidt. 1988. "Upward influence style: Relationship with performance, salary, and stress." Administrative Science Quarterly, 33, 528-542.

Kotter, J. P. 1979. "Managing external dependence." Academy of Management Review, 4, 87-102.

Kramer, R. M. 2000. "Political paranoia in organizations: Antecedents and consequences," pp. 47-88, in S. B. Bacharach and E. J. Lawler (eds.), Organizational Politics. Stamford, CT: JAI Press.

Kramer, R. M., and M. A. Neale (eds.). 1998. Power and Influence in Organizations. Thousand Oaks, CA: Sage.

Krochmal, Z. 2000. Brazen-faced Military Police: Personal Stories of Military Investigator. Tel Aviv: Yedioth Ahronoth.

Kumar, P., and R. Ghadially. 1989. "Organizational politics its effects on members of organizations." Human Relations, 42, 305-314.

Lasswell, H. 1958. Politics: Who Gets What, When, How. New York: Meridian.

Lasswell, H., and A. Kaplan. 1950. Power Society. New Haven, CT: Yale University Press.

Laumann, Edward O., and D. Knoke. 1987. The Organization State: Social Choice in National Policy Domains. Madison: The University of Wisconsin Press.

Lawler, E. J., and S. B. Bacharach. 1979. "Power-dependence in individual bargaining: The unexpected utility of influence." Industrial Labor Relations Review, 32, 196-204.

Lukes, S. 1974. Power: A Radical View. London: Macmillan.

Lukes, S. (ed.). 1986. Power. Oxford, UK: Basil Blackwell.

March, G. J. 1955. "An introduction to the theory of measurement of influence." American Political Science Review, 49, 431-451.

March, J. G. 1962. "The business firm as a political coalition." Journal of Politics, 24, 662678.

March, J. G. 1966. “The power of power,” pp. 39-70, in D. Easton (ed.), Varieties of Political Theory. Englewood Cliffs, NJ: Prentice-Hall.

March, J. G., and J. P. Olsen. 1989. Rediscovering Institutions: The Organizational Basis of Politics. New York: Free Press.

March, J. G., and H. A. Simon. 1958. Organizations. New York: Wiley.

Martin, R. 1977. The Sociology of Power. London: Routledge and Kegan Paul.

Martin, N. H., and J. H. Sims. 1971. "Power tactics," pp. 155-161, in D. A. Kolb, I. M. Rubin, and J. M. McIntyre (eds.), Organizational Psychology: A Book of Readings. Englewood Cliffs, NJ: Prentice-Hall.

Mayes, B. T., and R. W. Allen. 1977. "Toward a definition of organizational politics." Academy of Management Review, 2, 672-678. 
Mills, C. W. 1956. The Power Elite. New York: Oxford University Press.

Mintzberg, H. 1979. The Structuring of Organizations. Englewood Cliffs, NJ: Prentice-Hall.

Mintzberg, H. 1983. Power in and Around Organizations. Englewood Cliffs, NJ: PrenticeHall.

Mintzberg, H. 1984. "Power organizational life cycle." Academy of Management Review, 9, $207-224$.

Mintzberg, H. 1985. "The organization as a political arena." Journal of Management Studies, 22, 133-154.

Mitchell, T. R., and H. Hopper. 1998. "Power, accountability, and inappropriate actions." Applied Psychology, 47, 497-517.

Mizruchi, M. S., and L. B. Stearns. 1988. "A longitudinal study of the formation of interlocking directorates." Administrative Science Quarterly, 33, 194-210.

Molm, L. D. 1990. "Structure, action, outcomes: The dynamics of power in social exchange." American Sociological Review, 55, 427-447.

Molm, L. D. 1997. Coercive Power and Social Exchange. Cambridge: Cambridge University Press.

Morgan, G. 1986. Images of Organization. Beverly Hills, CA: Sage.

Nicolson, P. 1996. Gender, Power and Organization. London: Routledge.

Nohria, N., and R. Eccles. 1992. "Face to face: Making network organization work," pp. 288-308, in N. Nohria and R. Eccles (eds.), Network Organizations: Structure, Form, Action. Boston: Harvard University Press.

Oliver, C. 1990. "Determinants of interorganizational relationships: Integration and future directions." Academy of Management Review, 15, 241-265.

Parker, C. P., R. L. Dipboye, and S. L. Jackson. 1995. "Perceptions of organizational politics: An investigation of antecedents consequences." Journal of Management, 21, 891-912.

Parsons, T. 1963a. "On the concept of influence." Public Opinion Quarterly, 27, 37-62.

Parsons, T. 1963b. "On the concept of political power." Proceedings of the American Philosophical Society, June, 232-262. Reprinted in S. Lukes (ed.). 1986. Power, pp. 94-143. Oxford: Basil Blackwell.

Patti, R. J. 1974. "Organizational resistance and change: The view below." Social Service Review, 48, 371-372.

Perrow, C. 1961. "The analysis of goals in complex organizations." American Sociological Review, 26, 859-866.

Perrow, C. 1970. "Departmental power perspectives in industrial firms," pp. 59-89, in M. N. Zald (ed.), Power in Organizations. Nashville: Vanderbilt University Press.

Pettigrew, A. M. 1973. Politics of Organizational Decision-Making. London: Tavistock.

Pfeffer, J. 1978. “The micropolitics of organizations," pp. 29-50, in M. W. Meyer (ed.), Environments Organizations. San Francisco: Jossey-Bass.

Pfeffer, J. 1981. Power in Organizations. Marshfield, MA: Pitman.

Pfeffer, J. 1992. Managing with Power: Politics and Influence in Organizations. Boston: Harvard University Press.

Pfeffer, J. 1997. New Directions for Organization Theory. New York: Oxford University Press.

Pfeffer, J., and A. M. Konrad. 1991. "The effects of individual power on earnings." Work and Occupations, 18, 385-414.

Pfeffer, J., and W. L. Moore 1980. "Power in university budgeting: A replication extension." Administrative Science Quarterly, 25, 637-653.

Pfeffer, J., and G. R. Salancik. 1978. The External Control of Organizations. New York: Harper \& Row.

Pichault, F. 1995. "The management of politics in technically related organizational change." Organization Studies, 16, 449-476. 
Powell, W. 1990. "Neither market nor hierarchy: Net forms of organizations," pp. 295336, in B. M. Staw and L. L. Cummings (eds.), Research in Organizational Behavior, Vol. 12. Greenwich, CT: JAI Press.

Provan, K. G. 1980. "Recognizing, measuring, and interpreting the political power distinction in organizational research." Academy of Management Review, 5, 549-560.

Provan, K. G., J. M. Beyer, and C. Kruytbosch. 1980. "Environmental linkages power in resource dependence relations between organizations." Administrative Science Quar. terly, 25, 200-225.

Raven, B. H. 1992. "A power/interaction model of interpersonal influence: French and Raven thirty years later." Journal of Social Behavior and Personality, 7, 217-244.

Reed, M. 1989. The Sociology of Management. New York: Harvester Wheatsheaf.

Riesman, D., N. Glazer, and R. Denney. 1961. The Lonely Crowd: A Study of the Changing American Character. New Haven: Yale University Press.

Russell, B. 1938. Power: A New Social Analysis. New York: Norton.

Sagie, S. 1990. "Intra-organizational power and information systems unit." Ph.D. diss., The Technion-Israel Institute of Technology, Haifa (Hebrew).

Salancik, G. R., and J. Pfeffer. 1974. "The bases and uses of power in organizational decision-making: The case of a university." Administrative Science Quarterly, 19, 453473.

Samia, Y. T. 2004. "Organizational climate in field units of Israel defence forces." Ph.D. diss., University of Haifa (Hebrew).

Samuel, Y. 1979. "An exchange and power approach to the concept of organizational effectiveness." Department of Sociology Anthropology, Tel Aviv University, Israel (mimeograph).

Samuel, Y. 1996. Organizations: Features, Structures, Processes, $2^{\text {nd }}$ ed. Haifa: University of Haifa Press \& Zmora-Bitan (Hebrew).

Samuel, Y. 2000. The Political Game: Power and Influence in Organizations. Haifa: The University of Haifa Press \& Zmora-Bitan Publishers.

Samuel, Y., and M. B. Zelditch, Jr. 1989. "Expectations, shared awareness, and power," pp. 288-312, in J. Berger, M. Zelditch, and B. Anderson (eds.), Sociological Theories in Progress, vol. 3. Newbury Park, CA: Sage.

Samuel, Y., and C. Jacobsen (1997). "A System dynamics model of planned organizational change." Computational \& Mathematical Organization Theory, 3, 151-171.

Savage, M., and A. Witz (eds.). 1992. Gender Bureaucracy. Oxford: Blackwell.

Schein, E. H. 1977. "Individual power political behavior." Academy of Management Review, 2, 64-72.

Schein, E. H. 1996. "Culture: The missing concept in organization studies." Administrative Science Quarterly, 41, 181-196.

Schmidt, S. M., and D. Kipnis. 1987. “The perils of persistence.” Psychology Today, 21, 32-34.

Scott, W. R. 1992. Organizations: Rational, Natural, and Open Systems, 3rd ed. Englewood Cliffs, NJ: Prentice-Hall.

Selzinck, P. 1949. TVA and the Grass Roots. Berkeley: University of California Press.

Shenhav, Y. A. 1999. Manufacturing Rationality: Engineering Foundations of the Managerial Revolution. New York: Oxford University Press.

Stevenson, W. B., J. L. Pearce, and L. W. Porter. 1985. "The concept of 'coalition' in organization theory research." Academy of Management Review, 10, 256-268.

Tannenbaum, A. S. 1968. Control in Organizations. New York: McGraw-Hill.

Tedeschi, J. T., and T. V. Bonoma. 1972. "Power and Influence: An Introduction," pp. 149, in J. T. Tedeschi (ed.), The Social Influence Processes. Chicago: Aldine.

Tedeschi, J. T., B. R. Schlenker and T. V. Bonoma. 1973. Conflict, Power, Games. New York: Academic Press. 
Thibaut, J., and H. H. Kelly. 1961. The Social Psychology of Groups. New York: Wiley. Thompson, J. D. 1967. Organizations in Action. New York: McGraw-Hill.

Thompson, P., and D. McHugh. 1995. Work Organizations: A Critical Introduction. London: Macmillan.

Tushman, M. L., and E. Romanelli. 1983. "Uncertainty, social location, an influence in decision making: A socioeconomic analysis." Management Science, 29, 12-23.

Vigoda, E. 1997. “Organization Politics: Features, Factors, and Implications of Interpersonal Influence Processes on Workers Performance in the Israeli Public Administration." Ph.D. diss., University of Haifa (Hebrew).

Vigoda, E. 2000. "Organizational politics, job attitudes, work outcomes: Exploration and implications for the public sector." Journal of Vocational Behavior, 57, 326-347.

Vigoda, E. 2003. Developments in Organizational Politics. Cheltenham: Edward Ellgar

Weber, M. 1947. The Theory of Social Economic Organization. Trans. A. M. Henderson and T. Parsons. New York: Free Press.

Weber, M. 1964. Religion in China: Confucianism and Taoism. New York: Macmillan.

Weick, K. E. 1979. The Social Psychology of Organizing. $2^{\text {nd }}$ ed. Reading, MA: EddisonWesley.

Weick, K. 2001. Making Sense of Organization. Oxford: Blackwell.

Westphal, J. D., and J. Zajac. 1995. "Who shall govern? CEO/board power, demographic similarity, new directors selection." Administrative Science Quarterly, 40, 60-83.

Williamson, O. E. 1975. Markets Hierarchies: Analysis Antitrust Implications. New York: The Free Press.

Williamson, O. E. 1981. "The economics of organizations: The transaction cost approach." American Journal of Sociology, 87, 548-577.

Williamson, O. E. (ed.). 1995. Organization Theory: From Chester Barnard to the Present Beyond. New York: Oxford University Press.

Wrong, D. H. 1968. "Some problems in defining social power." American Journal of Sociology, 73, 673-681.

Wrong, D. H. 1996. Power: Its Forms, Bases, Uses, $2^{\text {nd }}$ ed. New Brunswick, NJ: Transaction Publishers.

Yuchtman, E., and S. E. Seashore. 1967. "A system resource approach to organizational effectiveness." American Sociological Review, 32, 891-903.

Yukl, G., and J. B. Tracey. 1992. "Consequences of influence tactics used with subordinates, peers, and the boss." Journal of Applied Psychology, 77, 525-535.

Zald, M. N. (ed.). 1969. Power in Organizations. Nashville: Vanderbilt University Press. 